doi: 10.32620/oikit.2019.86.03

УДК 629.7.01

О. Г. Гребеніков, А. М. Гуменний, О. Д. Донець*, С. В. Трубаєв, А. С. Чумак

\title{
Особливості інтегрованого проектування регіональних пасажирських літаків
}

\author{
Національний аерокосмічний університет ім. М. Є. Жуковського «XАІ» \\ `Державне підприємство «Антонов»
}

\begin{abstract}
Наведено особливості інтегрованого проектування конкурентоспроможних регіональних пасажирських літаків, призначених для перевезення пасажирів, багажу, пошти та вантажів на внутрішніх і міжнародних авіалініях 3 можливістю експлуатації на аеродромах зі штучним покриттям і підготовлених ґрунтових злітно-посадкових смугах (ЗПС). Застосування запропонованих особливостей концепції та принципів, а також їх реалізація дозволить створити літаки для заміни попереднього покоління парку регіональних пасажирських літаків. Концепція та принципи базуються на використанні систем інтегрованого проектування та виробництва.

Запропоновано метод дослідження впливу параметрів літака на аеродинамічні й масові характеристики за умови забезпечення вимог авіаційних правил (АП). Метод апробовано при інтегрованому проектуванні різних модифікацій пасажирських літаків ДП «АНТОНОВ».

Описано особливості створення тривимірної комп'ютерної моделі майстер-геометрії літака, що проектується, розроблення моделі розподілу простору, аналітичних еталонів силових елементів конструкцій, які створюються методами аналітичної геометрії за допомогою комп'ютерних інтегрованих систем CAD/CAM/CAE/PLM в єдиному інформаційному середовищі підтримки життєвого циклу літака.

Основні технічні характеристики літака, що проектується з урахуванням запропонованих пропозицій, повністю відповідає нормам льотної придатності та перевищують характеристики літаків-аналогів. За потребою можна врахувати особливості експлуатації літака на аеродромах з малопідготовленими і ґрунтовими ЗПС, надати змогу застосовувати його на будь-яких повітряних трасах, у простих і складних метеоумовах, удень і вночі, а також на маршрутах зі значною інтенсивністю польотів при високому рівні комфрорту, що забезпечує конкурентоспроможність літака на світовому ринку.

Ключові слова: літак; проектування; загальний вигляд; параметри; розрахунок маси; компонування; параметрична модель; майстер-геометрія літака; модель розподілу простору; аналітичні еталони силових елементів конструкцій; аеродинамічна якість; конкурентоспроможність.
\end{abstract}

Результати досліджень перспектив розвитку світового цивільного літакобудування свідчать про подальше збільшення обсягів авіаперевезень і потреб світового ринку в нових пасажирських авіалайнерах $[1,2]$.

Вітчизняний ринок пасажирських авіаперевезень потребує близько 50 літаків на заміну морально й фрізично застарілих літаків типу Ту-134, призначених для перевезення 75 - 85 пасажирів, багажу, пошти і вантажів 3 діапазоном практичної дальності 2500...5000 км. При цьому новий літак має бути здатним до модифікації і збільшення пасажиромісткості. Потреба в нових регіональних літаках у 2007 - 2027 рр. складе 11000 одиниць, близько 53 \% 3 яких - літаки на 100 - 149 місць, а $37 \%$ - на 60 - 99 місцями. При цьому авіакомпанії насамперед зацікавлені у зниженні експлуатаційних витрат [1, 2].

Метою інтегрованого проектування $€$ створення нового пасажирського літака шляхом розроблення особливостей концепції, принципів та методів 
одержання виконання технічного завдання, дотримання вимог нормативних документів (AП [6]), CS [7]) та забезпечення одержання максимальної технічної ефективності. При цьому літак слід проектувати з урахуванням вимог комфорту та економічності в експлуатації (рисунок 1).

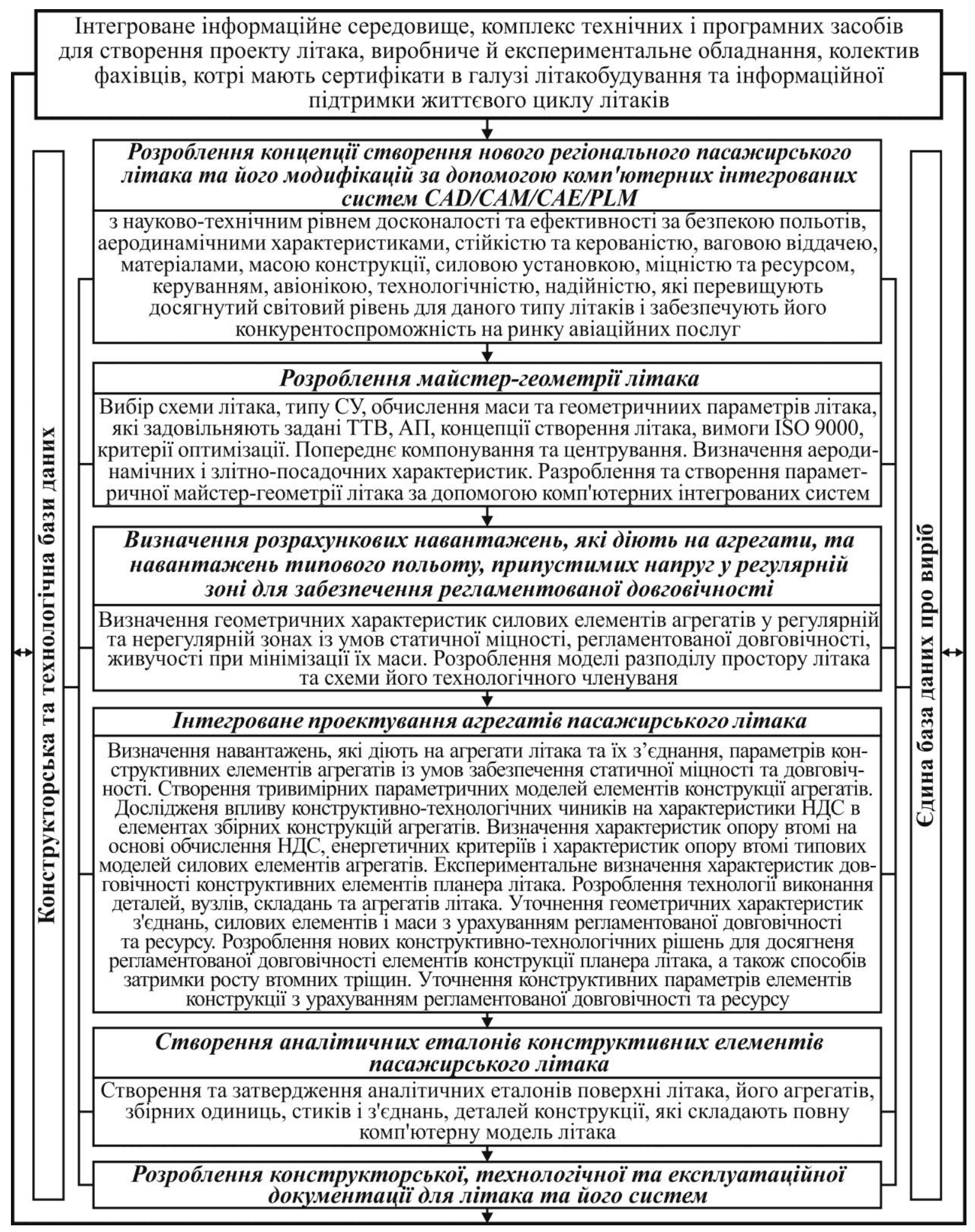

Рис. 1. Особливості концепції інтегрованого проектування базового регіонального пасажирського літака 
Інтегроване проектування охоплює проектування й комп'ютерне параметричне тривимірне моделювання конструкції літака в цілому та окремих його частин і містить:

- формування інтегрованого інфрормаційного простору, комплексу технічних і програмних заходів для створення проекту літака, виробничої та дослідної бази, колективу фрахівців;

- розроблення концепції створення нового літака або модифікації вже існуючого з використанням комп'ютерних інтегрованих систем проектування;

- загальне проектування та конструювання окремих частин, з'єднань, систем тощо;

- комп'ютерне моделювання літака 3 використанням систем CAD/CAM/CAE/PLM, що містить як розроблення майстер-геометрії, так і аналітичних еталонів конструкцій і елементів;

- створення конструкторської, технологічної та експлуатаційної документації.

На основі запропонованої концепції [4] були розроблені принципи інтегрованого проектування пасажирського літака: літака.

1. Принцип створення аналітичних еталонів елементів пасажирського

Тривимірні комп'ютерні моделі майстер-геометрії, розподілу простору, аналітичні еталони елементів конструкцій створюються методами аналітичної геометрії за допомогою інтегрованих систем CADICAMICAE\PLM в єдиному інфрормаційному середовищі підтримки життєвого циклу літаків.

\section{2. Принцип створення майстер-геометрії вигляду літака.}

Параметри загального вигляду нового літака мінімальної маси та регламентованої довговічності мають задовольняти заданим перспективним тактико-технічним вимогам, авіаційним правилам, концепції створення нового літака. У символьному вигляді запишемо їх так:

$$
\begin{aligned}
& \text { TTВ, АП } \rightarrow \text { схема літака } \rightarrow \\
& m_{0}=\frac{m_{\text {сл.н }}+m_{\text {об.упр }}+m_{\text {ком }}}{1-\left[\bar{m}_{\kappa}\left(p, n_{p}, N_{\text {рег }}, \lambda, \text { ОГП }\right)+\bar{m}_{c y}\left(p, t_{0}, \gamma_{\partial в}, R, N_{\partial в}\right)+\bar{m}_{n}\left(p, C_{T}, k, L\right)\right]} \\
& m_{0 \min } \rightarrow p_{\text {opt }} \rightarrow t_{\text {opt }} \rightarrow P_{0} \rightarrow S_{i} \rightarrow \text { профрілі } i_{i} \rightarrow\left(l_{i}, \lambda_{i}, \chi_{i}, \bar{c}_{i}, \eta_{i}, D_{\phi}, L_{B O}, L_{\Gamma О}\right) \\
& \rightarrow\left(\bar{x}_{T}-\bar{x}_{F}\right) \rightarrow \text { аналітичний еталон поверхні літака. }
\end{aligned}
$$

3. Принцип проектування агрегатів літака.

Конструктивні параметри та технологія виконання регулярних зон (р.з.) агрегатів літакових конструкцій мають забезпечувати безпеку польотів, аеродинамічну якість, сприйняття розрахункових руйнівних навантажень, регламентовану довговічність при навантаженнях, еквівалентних навантаженнях типового польоту в експлуатаційному середовищі, заданий коефіцієнт утомної якості $\left(K_{y}\right)$, задану якість зовнішньої поверхні, ступінь герметичності та ін.

Для регулярних зон конструкції літака реалізація принципу потребує прийняти до уваги крім задоволення вимог, що вище вказані, ще й такі нерівності: 


$$
\begin{gathered}
P_{\text {руй }} \geq P_{\text {розр }}\left(K \Pi_{p .3}, \sigma_{\text {др.3 }}\left(N_{\text {реглам } .3}\right)\right) ; \\
N_{\text {реглам }} \leq N_{\text {розр.р.3 }}\left(K \Pi_{p .3}, \sigma_{0 е к в}, \sigma_{\kappa}, T B\right) ; \\
\Delta_{3}<0 \text { при } P=P_{\text {експл }} ; \Delta h \leq 0,05 \text { мм; } K_{y} \leq 3 .
\end{gathered}
$$

4. Принцип проектування нерегулярних зон елементів конструкції агрегатів літака.

Конструктивні параметри і технологія виконання нерегулярних зон (н.р.з.) мають забезпечувати сприймання розрахункових зусиль в нерегулярній зоні при статичному навантаженні, регламентовану довговічність, якість зовнішньої поверхні і герметичність, такими, що дорівнюють характеристикам регулярної зони або перевищують їх. Для реалізації принципу доцільно також використати такі нерівності:

$$
\begin{gathered}
P_{\text {руйн }} \geq P_{\text {розр }}\left(K \Pi_{\text {н.р.3 }}, \sigma_{\text {дн.р.з }}\left(N_{\text {регламн.р.3 }}\right)\right) ; \\
\Delta h_{\text {н.p.3 }} \leq \Delta h_{p .3} ; \Delta_{3 н . p .3}<\Delta_{3 p .3} ; \\
N_{\text {реглам }} \leq \min \left(N_{\text {розр.н.р.3 }}\left(K \Pi_{\text {н.р.3. }},\left(\sigma_{0 \text { екв }} \cdot \varepsilon_{\text {екв }}\right), \sigma_{\kappa}, T B\right) ;\right. \\
\left.N_{\text {експ }}\left(K \Pi_{\text {н.р.3 }}, \sigma_{0}, \sigma_{\kappa}, T B\right)\right) .
\end{gathered}
$$

5. Принцип підтримки та досягнення живучості силових елементів планера літака з втомними тріщинами.

Конструктивні параметри збірних літакових конструкцій, що безпечно руйнуються, мають забезпечувати можливість контролю критичних місць, виявлення втомних тріщин і застосування прогресивних способів затримки їх зростання, відновлення несучої здатності i герметичності пошкодженої конструкції. Принцип підтримки та досягнення живучості силових елементів планера літака з втомними тріщинами базується на нерівностях:

$$
\left(N_{\text {зал. СЗРТУ }} / N_{\text {зал. з тр }}\right)>1 ; \Delta_{3, \text { СЗРТУ }}<0 .
$$

Особливостями використання концепції проектування регіональних пасажирських літаків $є$ забезпечення рівня досконалості, що перевершує існуючі аналоги за льотно-технічними, ресурсними, експлуатаційними та економічними характеристиками [3] і потребує вибір схеми літака та використання методу аналізу впливу параметрів літака, що проектується за такими характеристиками. При цьому необхідно вирішати питання стосовно критерію ефективності та переліку параметрів, що мають значення.

$\mathrm{Ha}$ етапі вибору параметрів загального вигляду регіонального пасажирського літака як критерій ефективності доцільно використовувати злітну масу літака, а як значущих параметрів розглядувати питоме навантаження на крило літака, стартову тягоозброєність силової установки та геометричні параметри зовнішнього вигляду літака, які визначають його аеродинамічні характеристики. 3 урахуванням вимог ТЗ та забезпечення спадкоємності конструкції вирішують питання щодо схеми літака.

Для ілюстрації результатів параметричного аналізу літака, що проектується, використано літак Ан-148 та його модифікації, технічне завдання на проектування та порівняльний аналіз характеристик існуючих конкурентоспроможних літаків [4]. Застосовано нормальну аеродинамічну схему з високо розташованим крилом помірної стрілоподібності з розвиненою 
механізацією. Два ТРДД розташовані на пілонах під крилом. Хвостове оперення має Т-подібну схему. Фюзеляж літака $\epsilon$ самостійним модулем 3 вузлами кріплення опор шасі, крила, вертикального й горизонтального оперення. У фрюзеляжі розміщено герметичну кабіну екіпажу і пасажирський салон, відсік радіолокатора, відсік БРЕО та інше обладнання. Шасі - триопорне, що прибирається в польоті, з носовим стояком, основні опори - двостоякові (рисунок 2). Необхідну кількість членів екіпажу 5 осіб встановлено 3 урахуванням вимог авіаційних правил щодо кількості пілотів й бортпровідників.

Розрахунок злітної маси виконуємо у кількох наближеннях. У нульовому наближенні відносні маси конструкції, силової установки, устаткування й палива приймаємо незалежними від параметрів та визначаємо на основі статистичних даних [3]:

$$
m_{0}^{0}=\frac{m_{\text {сл. }{ }}+m_{\kappa . H}}{1-\left(\bar{m}_{\kappa о н}+\bar{m}_{c y}+\bar{m}_{\text {об.ynp }}+\bar{m}_{n}\right)}
$$

де $m_{\text {сл.н }}$ - маса службового навантаження, кг; $m_{\kappa . н}$ - маса комерційного навантаження літака, кг; $\bar{m}_{\kappa o н}$ - відносна маса конструкції; $\bar{m}_{c y}$ - відносна

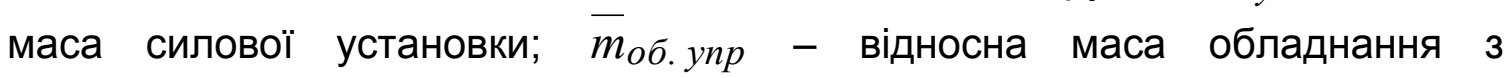
урахуванням устаткування та управління; $m_{n}$ - відносна маса палива.

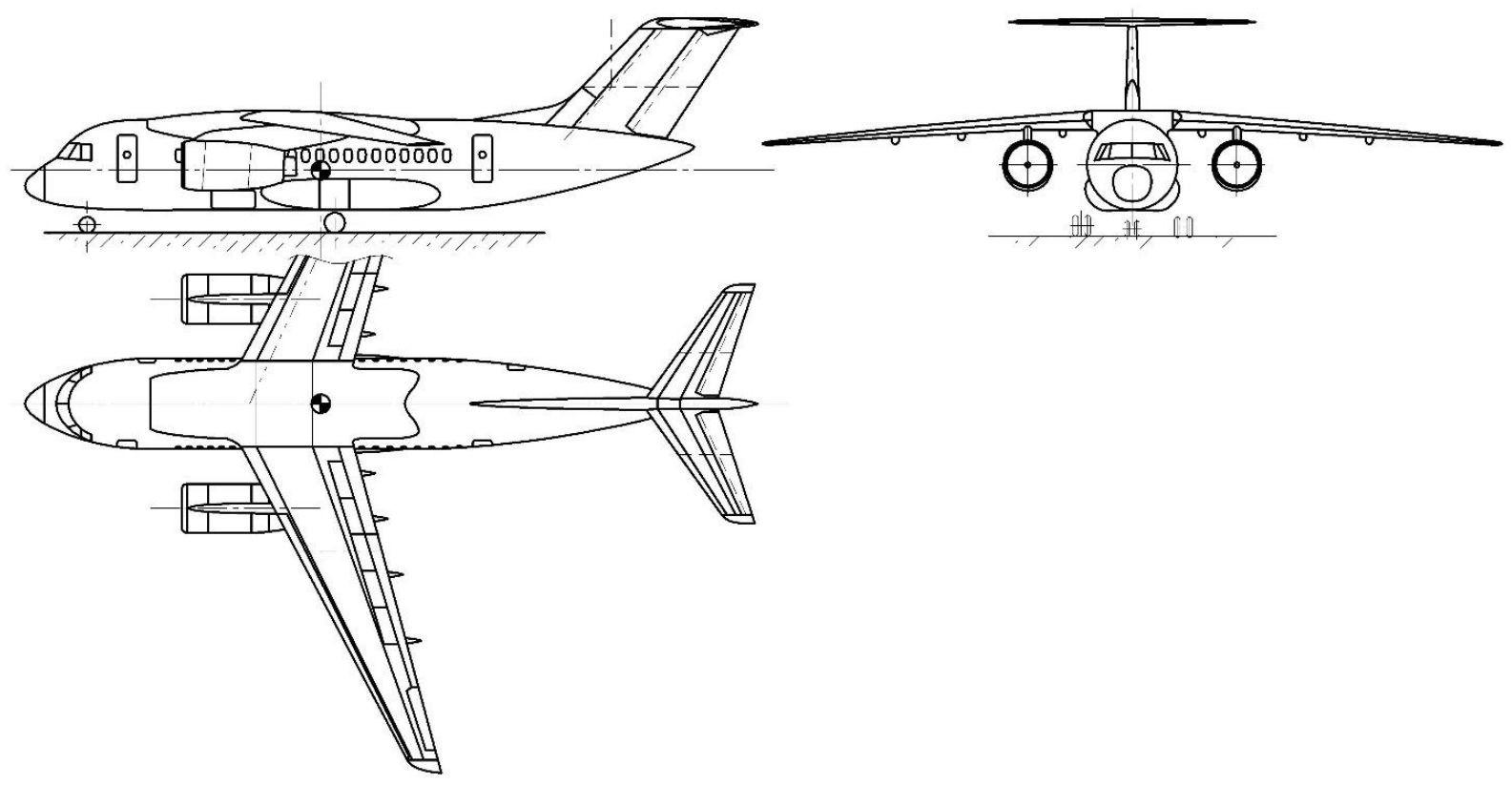

Рис. 2. Схема літака

Для різних модифікацій літака Ан-148 прийнято $m_{c л}=720$ кг; $\bar{m}_{\kappa о н}=0,28$; $\bar{m}_{c . y}=0,1 ; \bar{m}_{о б}=0,1$ та отримано $m_{0}^{0}=37700$ кг $\left(n_{n a c}=80, L=2100\right.$ км, $\left.\bar{m}_{n}=0,22\right)$ та $m_{0}^{0}=42240$ кг $\left(n_{n a c}=80, L=4200\right.$ км, $\left.\bar{m}_{n}=0,36\right)$.

У першому наближенні формула для визначення злітної маси літака $m_{0}^{\prime}$ має вигляд [3, 8, 9, 10] 


$$
m_{0}^{\prime}=\frac{m_{\text {сл.н }}+m_{\kappa . н}+m_{\text {об.упр }}}{1-\left[\bar{m}_{\kappa о н}\left(m_{0}^{0}, p, n_{p}, N_{p e г}, \lambda, O \Gamma \Pi, \ldots\right)+\bar{m}_{c y}\left(p, t_{0}, \gamma_{\partial b}, R, N_{\partial b}, \ldots\right)+\bar{m}_{n}\left(p, C_{T}, k, L, \ldots\right)\right]} .
$$

Відносні маси конструкції, силової установки та палива в першому наближенні визначено такими, що залежать від параметрів літака. Масу

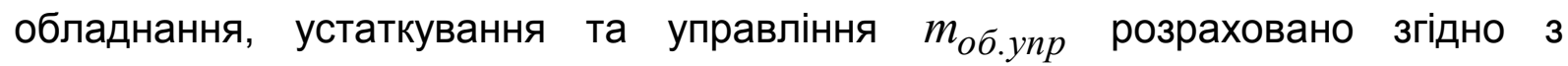
переліком обладнання, складеним за даними щодо літаків-аналогів та 3 урахуванням вимог технічного завдання.

Масу службового навантаження $m_{\text {сл.н }}$ пасажирського літака визначаємо за фрормулою [13]

$$
m_{\text {сл.н }}=m_{\text {eк }} \cdot n_{e \kappa}+\Delta m_{c л},
$$

де $m_{e \kappa}=80$ кг - маса одного члена екіпажу; $n_{e \kappa}-$ кількість членів екіпажу, осіб;

$\Delta m_{\text {сл.н }}$ - маса службового обладнання літака, кг.

Аналіз літературних джерел і статистичних даних щодо існуючих літаків дає змогу пропонувати розраховувати масу службового обладнання, кг, пасажирських літаків коротких та середніх авіаліній за такою формулою [4, 13]:

$$
\Delta m_{c л}=8,617 n_{n a c}+3,53\left(n_{n a c} \bar{m}_{n} / K_{\text {вid }}\right)^{2 / 3},
$$

де $n_{n a c}$ - кількість пасажирів, чол.; $\bar{m}_{n}$ - статистичне значення відносної маси палива; $K_{\text {від }}=m_{\kappa о м} / m_{0}$ - статистичне значення коефіцієнта віддачі.

Для розрахунку маси службового навантаження, кг, пасажирських літаків дальніх авіаліній пропонують формулу [4, 13]

$$
\Delta m_{c л}=14,97 n_{n a c}+4,121\left(n_{n a c} \bar{m}_{n} / K_{\text {від }}\right)^{2 / 3} \text {. }
$$

Відносні маси конструкції, силової установки та палива визначаємо залежно від параметрів літака на основі аналітичних залежностей 3 урахуванням поправкових коефіцієнтів. Ці аналітичні залежності дають змогу провести аналіз впливу параметрів літака на його злітну масу з подальшим знаходженням значень мінімальної маси та оптимальних параметрів літака.

Відносну масу силової установки $\bar{m}_{c y}$ визначаємо за фрормулою

$$
\bar{m}_{c y}=R \gamma_{\partial s} t_{0 \max }
$$

де $\boldsymbol{R}$ - коефріцієнт, що враховує збільшення маси силової установки порівняно 3 масою двигунів:

$$
R=k_{1}\left(1+0,1 \frac{n_{\text {дв.рев }}}{n_{\partial в}}\right)\left[1+\frac{0,0236}{\gamma_{\partial в}}\left(1,5+0,275 y^{0,75}\right)^{2}\right]
$$

де $\quad k_{1}$ - коефіцієнт, що враховує кількість та розташування двигунів на літаку; $n_{\partial в}-$ кількість двигунів на літаку; $n_{\text {дв.рев }}-$ кількість двигунів, обладнаних реверсом тяги; $\gamma_{д в}$ - питома вага двигуна, даН/даН; $y$ - ступінь двоконтурності двигуна. 
Стартову тягоозброєність $t_{0}$ для виконання розрахунків за наведеною формулою знаходимо як максимальну згідно з такими вимогами: забезпечення крейсерського польоту із заданою швидкістю та висотою, довжини розбігу перед зльотом; продовженого зльоту при відмові одного двигуна.

Стартову тягоозброєність, необхідну для забезпечення максимального числа $M$ на висоті $H$, визначаємо за фрормулою

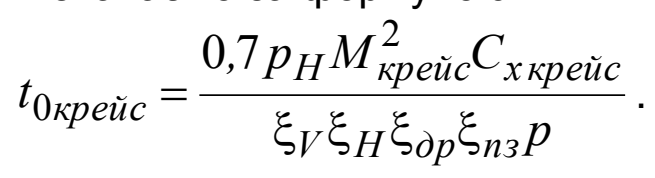

Дійсно, що на крейсерських режимах польоту

$$
\begin{aligned}
& C_{\text {хрейс }} \approx \frac{4}{3} C_{x 0}=\frac{4}{3}\left(F_{1}+F_{2} p\right) ;
\end{aligned}
$$

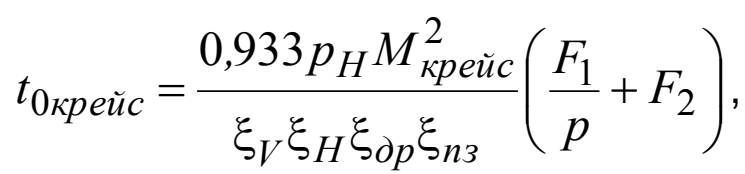

де $F_{1}=k_{\text {on }} C_{x \kappa p}-$ коефріцієнт лобового опору крила й оперення; $F_{2}=\frac{C_{x \phi}}{k_{\text {мid }}}$; $C_{x \phi}$ - коефіцієнт лобового опору фрюзеляжу, мотогондол, обтічників двигунів й шасі тощо; $k_{\text {мід }}$ - питоме навантаження на мідель, даН/м²; $p_{H}$ - атмос-

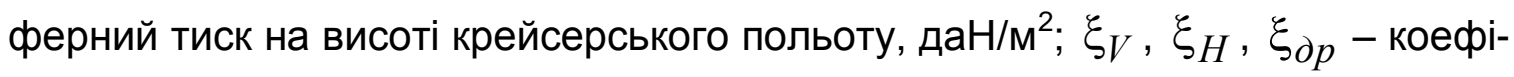
цієнти, що враховують зміну тяги двигуна залежно від швидкості й висоти польоту та режиму роботи двигунів; визначається 3 паспортних даних

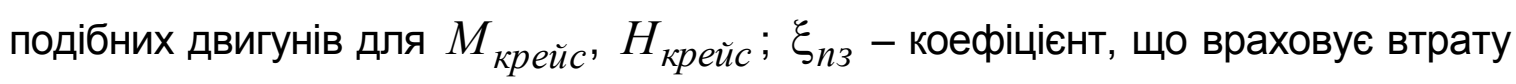
тяги, пов'язану з втратами швидкісного напору в повітрозабірниках.

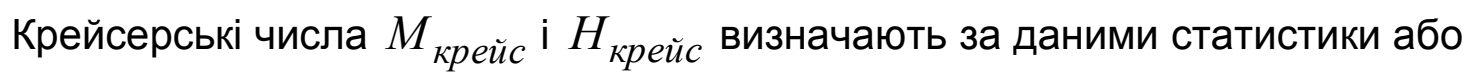
з досвіду експлуатації подібних літаків.

Стартову тягоозброєність, необхідну для забезпечення заданої довжини розбігу перед зльотом, визначаємо за формулою

$$
t_{0 p}=\frac{1}{\xi_{з л}}\left[\frac{0,832 p}{L_{p} C_{y з л}}+\frac{1}{3}\left(\frac{1}{K_{\text {зл }}}+2 f\right)\right]
$$

де $\xi_{\text {зл }}=\xi_{V} \xi_{H} \xi_{n 3} \xi_{\partial p}-$ коефріцієнти, що визначають для режимів зльоту $M=M_{o m p}$ та $H=0 ; L_{p}$ - довжина розбігу перед зльотом, задана в Т3, м; $f$ - коефіцієнт тертя коліс об поверхню ЗПС під час розбігу.

Стартову тягоозброєність, необхідну для забезпечення продовження зльоту при відмові одного двигуна під час розбігу, визначаємо так:

$$
t_{0 \theta}=\frac{n_{\partial в}}{\xi_{\text {зл }}\left(n_{\partial в}-1\right)}\left(\frac{1}{K_{3 л}}+\operatorname{tg} \theta_{3}\right)
$$


де $n_{\partial в}-$ кількість двигунів, установлених на літаку; $\operatorname{tg} \theta_{3}$ - градієнт набирання висоти на третьому етапі зльоту при відмові одного двигуна, що задається в Нормах Льотної Придатності літаків.

Вплив питомого навантаження та подовження крила на необхідну стартову тягоозброєність та відносну масу силової установки згідно 3 наведеними вимогами показано на рисунках 3, 4 .

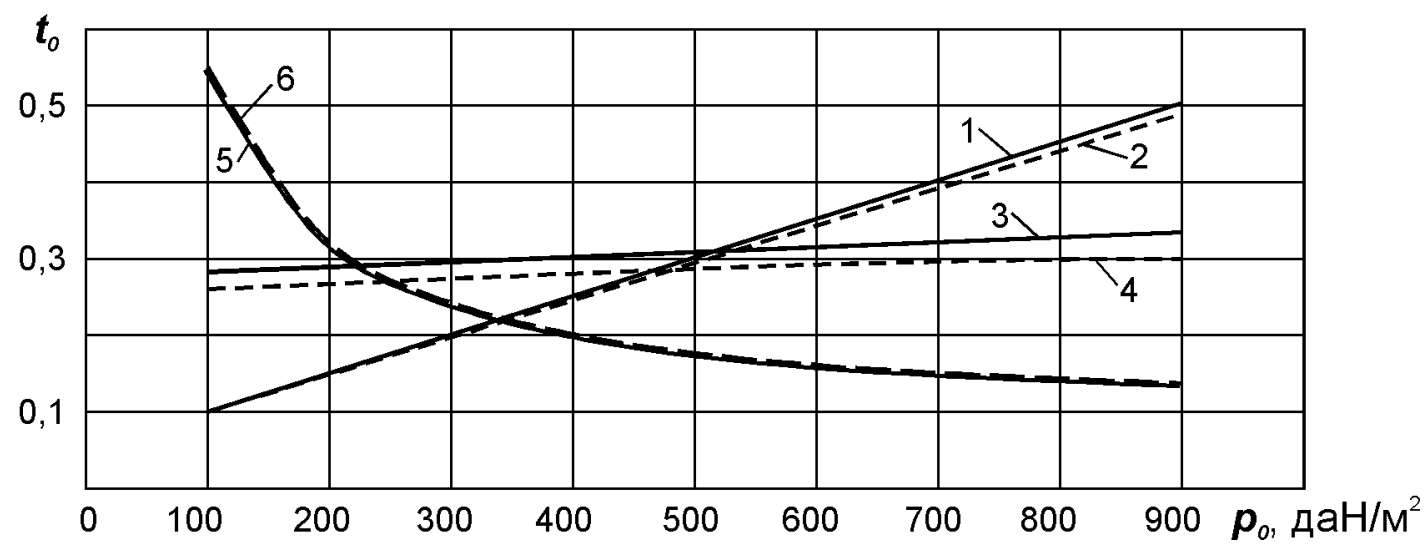

Рис. 3. Вплив питомого навантаження та подовження крила на необхідну стартову тягоозброєність:

- для забезпечення заданої довжини розбігу: $1-\lambda=8$; $2-\lambda=10$;

- для забезпечення безпеки зльоту: $3-\lambda=8 ; 4-\lambda=10$;

- для забезпечення крейсерської швидкості: $5-\lambda=8 ; 6-\lambda=10$

$$
\left(\eta=4, \chi_{n}=26^{\circ}, L=2500\right. \text { км) }
$$

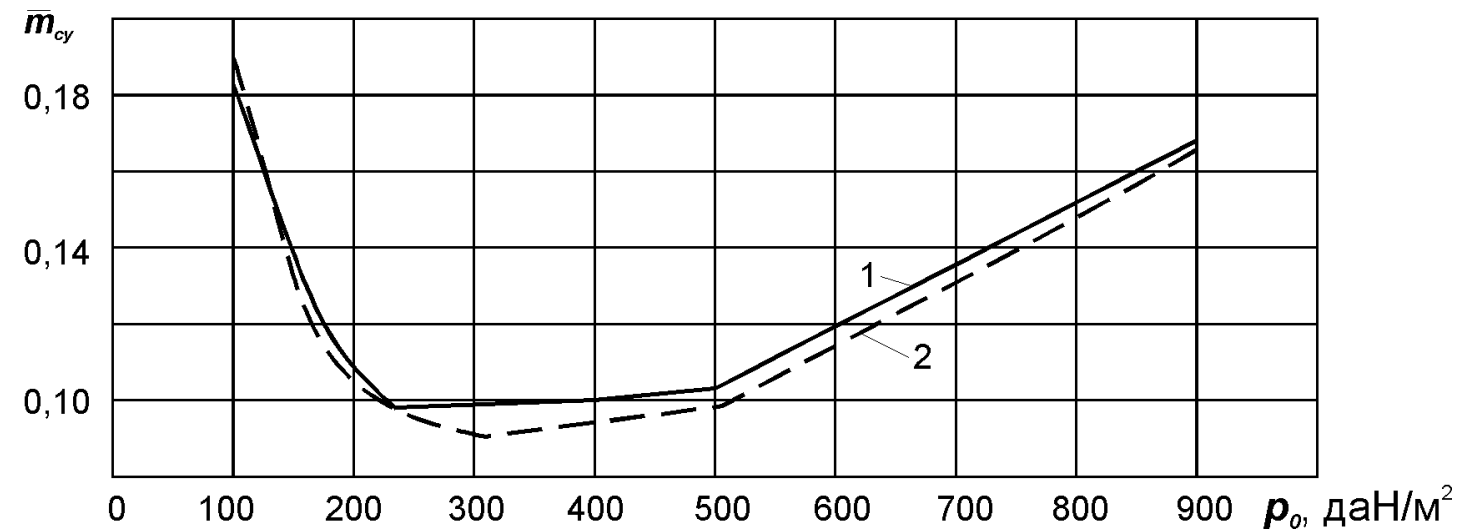

Рис. 4. Вплив питомого навантаження та подовження крила на відносну масу силової установки літака:

$$
1-\lambda=8 ; 2-\lambda=10\left(\eta=4, \chi_{n}=26^{\circ}, L=2500 \text { км }\right)
$$

Відносну масу палива $\bar{m}_{n}$ визначаємо як суму мас $[9,10]$ :

$$
\bar{m}_{n}=\bar{m}_{n . \text { H. }}+\bar{m}_{n . к р е и ̆ c}+\bar{m}_{n . \mu .3}+\bar{m}_{n .3 н . n}+\bar{m}_{n . \text { ocm }},
$$

де $\bar{m}_{n . н . в}-$ відносна маса палива, що використовується на зліт і набір висоти;

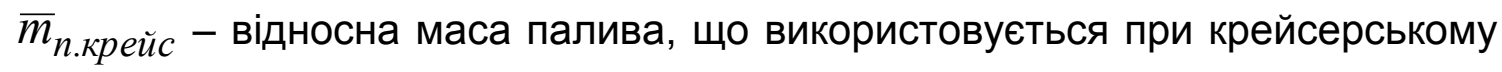




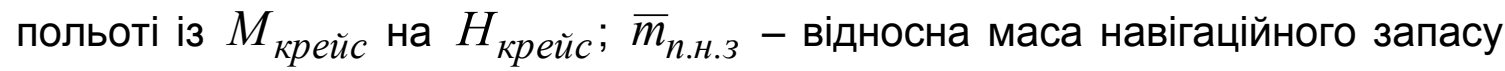
палива; $\bar{m}_{n . з н . n}$ - відносна маса палива, що використовується на зниження та посадку; $\bar{m}_{n . o c m}$ - відносна маса палива, що не може бути використано;

$$
\bar{m}_{n . \text {. }}=\frac{0,0035 H_{\text {nоч }}(1-0,03 y)}{1-0,004 H_{\text {nоч }}} ; \bar{m}_{n . \text { сн.n }}=0,002 H_{\text {кін }}(1-0,03 y)\left(1-0,023 H_{\text {кін }}\right) \text {, }
$$

де $H_{n о ч}, H_{\text {кін }}$ - значення початкової та кінцевої висоти крейсерського польоту, км; $y$ - ступінь двоконтурності двигуна.

Відносна маса палива, що використовується при крейсерському польоті:

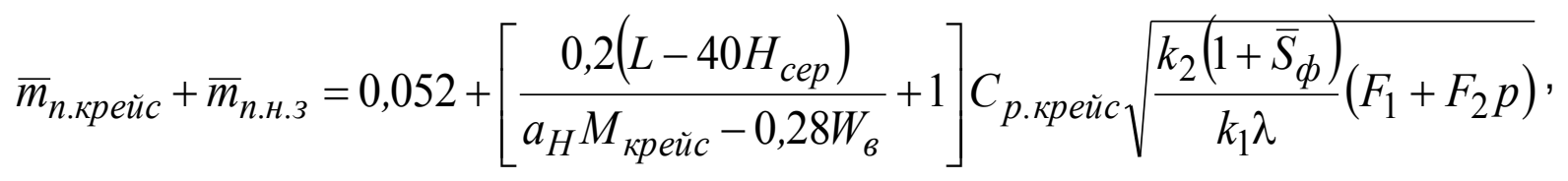

де $L$ - дальність польоту, км; $H_{c е p}=\left(H_{\text {поч }}+H_{\text {кін }}\right) / 2$ - середня висота крейсерського польоту, км; $a_{H}$ - швидкість звуку на середній висоті крейсерського польоту, м/с; $M_{\text {крейс }}$ - число Маха, що відповідає крейсерській

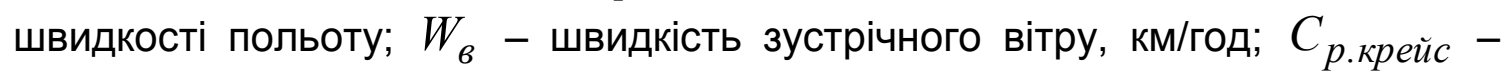
питома витрата палива на крейсерському режимі польоту, кг/даН·год.

Вплив питомого навантаження та подовження крила на відносну масу палива показано на рисунку 5.

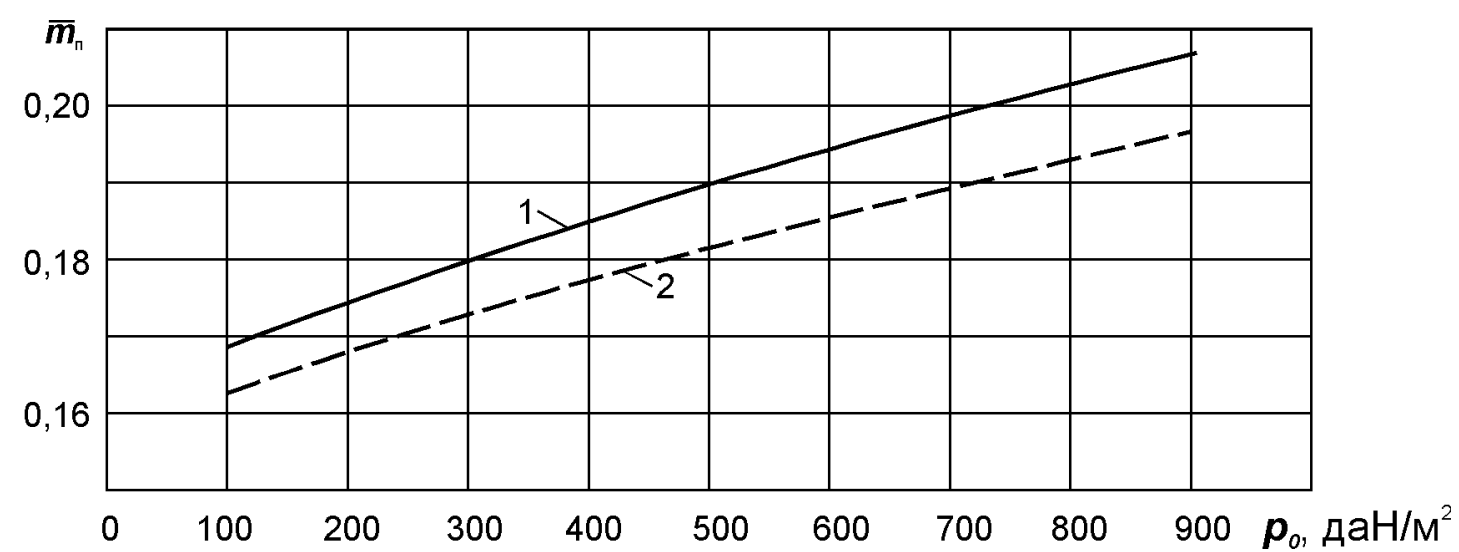

Рис. 5. Вплив питомого навантаження та подовження крила на відносну масу палива: $1-\lambda=8 ; 2-\lambda=10$ ( $\eta=4, \chi_{n}=26^{\circ}, L=2500$ км $)$

Відносна маса конструкції складається з відносних мас крила, фюзеляжу, оперення та шасі:

$$
\bar{m}_{\kappa o H}=\bar{m}_{\kappa p}+\bar{m}_{\phi}+\bar{m}_{o n}+\bar{m}_{u} .
$$

Для розрахунку відносної маси крила використаємо фрормулу [9, 10] 


$$
\bar{m}_{\kappa p}=\frac{7,2 k_{1} n_{A}^{p}\left(m_{0}^{0}\right)^{0,5} \varphi \lambda}{10^{4} p \bar{c}_{0}^{0,75} \cos ^{1,5} \chi_{0,25}} \cdot \frac{\eta+4}{\eta+1}+\frac{4,5 k_{2} k_{3}}{p}+0,015,
$$

де $p$ - питоме навантаження на крило, даН/ $\mathrm{M}^{2} ; k_{1}$ - коефіцієнт, що враховує тип панелей; $k_{2}$ - коефіцієнт, що враховує наявність напливів, інтерцепторів, передкрилків і тип закрилків; $k_{3}$ - коефріцієнт, що враховує тип паливних баків і тип герметизації; $n_{A}^{p}$ - коефіцієнт розрахункового перевантаження літака для розрахункового випадку $A ; \varphi=b-0,83 \bar{m}_{n}$ - коефріцієнт розвантаження крила паливом і двигунами; $\lambda, \bar{c}, \chi_{0,25}, \eta$ - значення подовження, відносної товщини профрілю, стрілоподібності й звуження крила, узяті для розрахунків.

Відносну масу фюзеляжу визначаємо за формулою Шейніна [10]

$$
\bar{m}_{\phi}=k_{1} \lambda_{\phi} d_{\phi}^{2}\left(m_{0}^{0}\right)^{i}+k_{2}+k_{3}+k_{4},
$$

де $k_{1}=4,56-0,441 d_{\phi}$ для схем із двигунами, розташованими на фюзеляжі; $k_{1}=3,4-0,26 d_{\phi}$ для схем із двигунами, розташованими на крилі, або при змішаному компонуванні двигунів (DC-10, L-1011); $i=-\left(0,77-0,01 d_{\phi}\right)$; $k_{2}$ - коефіцієнт, що враховує місце кріплення основних стояків шасі; $k_{3}$ - коефіцієнт, який враховує місце прибирання основних стояків шасі; $k_{4}$ - коефіцієнт, що враховує спосіб завантаження багажу.

Відносну масу оперення визначаємо за статистичною формулою [9]

$$
\bar{m}_{o n}=0,85 k_{n} k_{o n}^{c x} p^{-0,56} \bar{S}_{o n}^{1,16}\left(m_{0}^{0}\right)^{0,16}
$$

де $k_{n}=1$ при $p \leq 450$ даН $/ \mathrm{m}^{2} ; k_{n}=0,84$ при $p>450$ даН// ${ }^{2}$;

$\bar{S}_{o n}=\bar{S}_{2 . o}+\bar{S}_{6 . o} ; k_{o n}^{c x}=\frac{1,564-0,0011 S_{o n}}{3,1+0,0038 p}$ для низько розташованого горизонтального оперення; $k_{o n}^{c x}=\frac{1,33-0,0032 S_{o n}}{1,295+0,0028 p}$ для Т-подібного оперення; $S_{\text {on }}=\bar{S}_{\text {on }} \cdot\left(m_{0}^{0} / p\right)$.

Для розрахунку відносної маси шасі використовуємо рівняння [10]

$$
\bar{m}_{u}=k_{u} k_{d \phi} \frac{m_{0}^{0}+204000}{m_{0}^{0}+79000},
$$

де $k_{u}$ - коефіцієнт, що враховує кількість основних стояків шасі; $k_{d \phi}-$ коефріцієнт, що враховує вплив на масу шасі розмірів фюзеляжу і типу двигунів.

Результати розрахунків відносної маси літака показано на рисунку 6. 


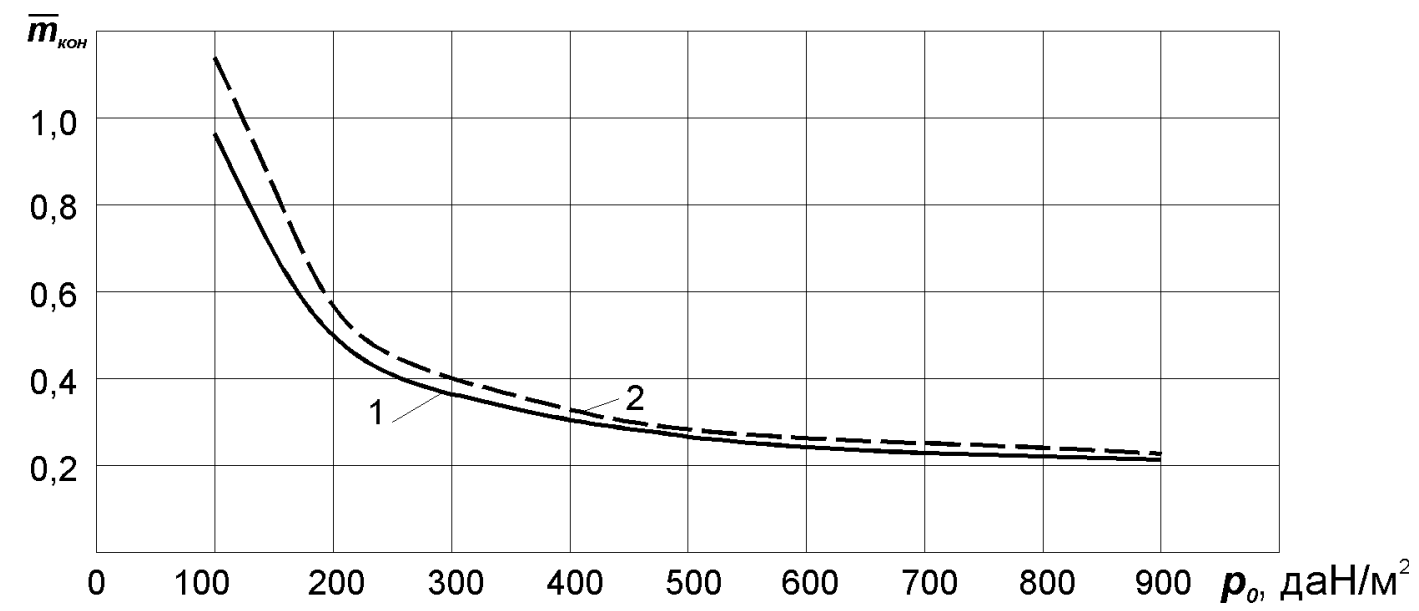

Рис. 6. Вплив питомого навантаження та подовження крила на відносну масу конструкції літака:

$$
1-\lambda=8 ; 2-\lambda=10\left(\eta=4, \chi_{n}=26^{\circ}, L=2500 \mathrm{kм}\right)
$$

Результати розрахунків злітної маси літака для різних комбінації параметрів показано на рисунках $7-9$.

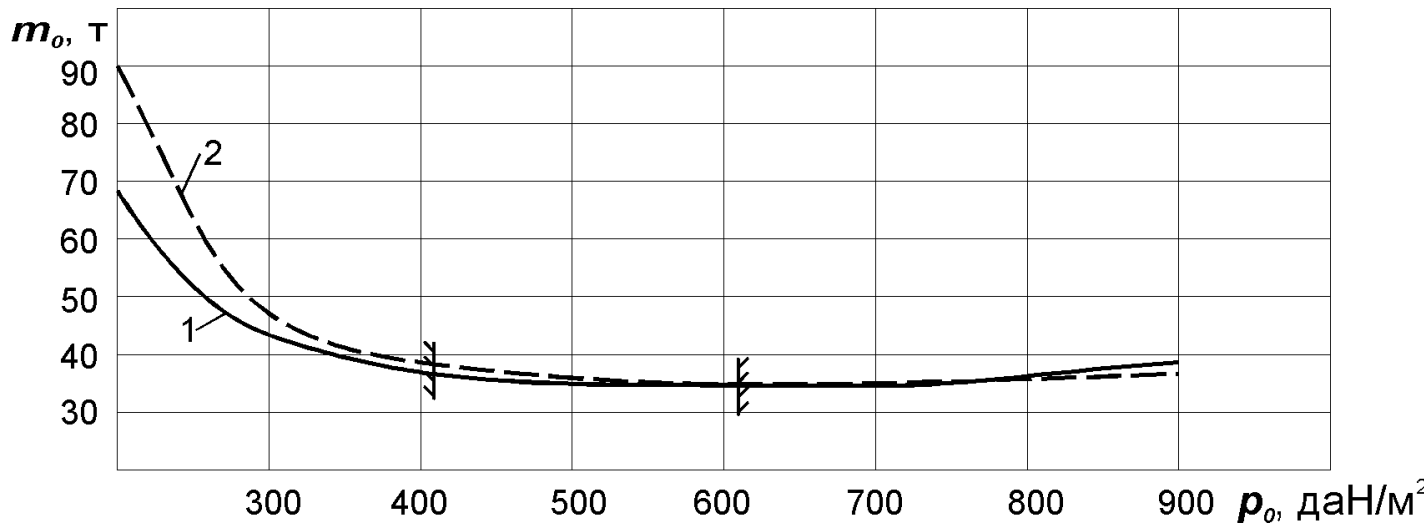

Рис. 7. Вплив питомого навантаження та подовження крила на злітну масу літака: $1-\lambda=8 ; 2-\lambda=10\left(\eta=4, \chi_{n}=26^{\circ}, L=2500\right.$ км $)$

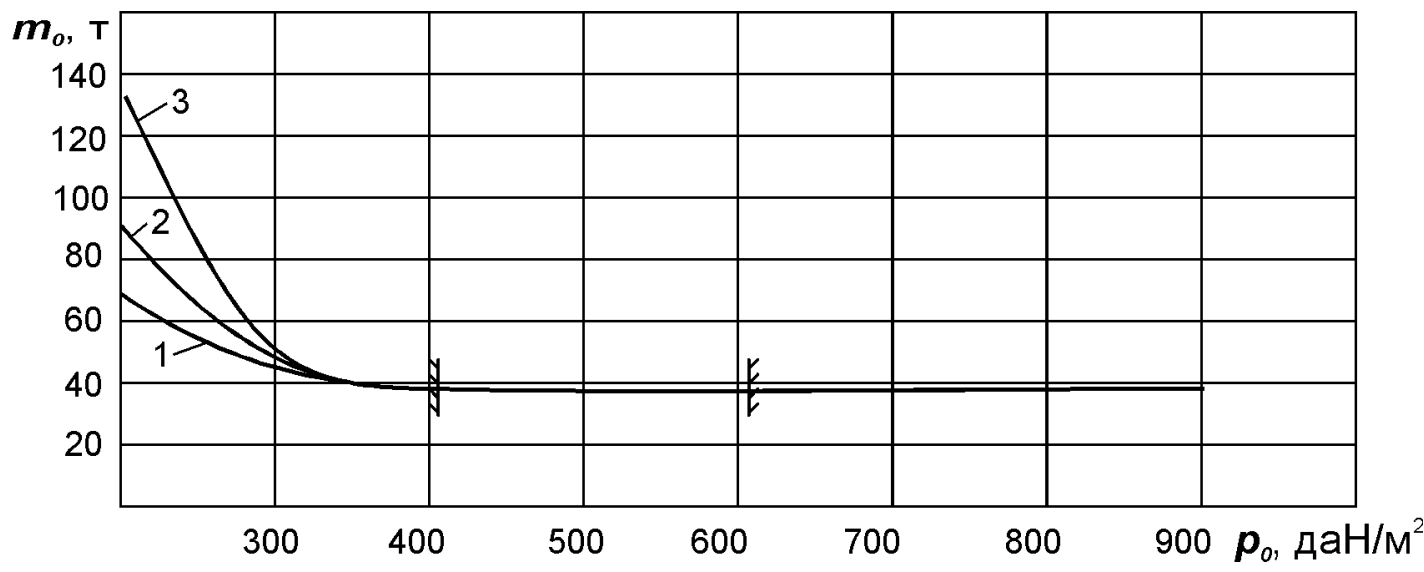

Рис. 8. Вплив питомого навантаження та звуження крила на злітну масу літака:

$1-\eta=3 ; 2-\eta=4 ; 3-\eta=5\left(\lambda=9,6, \chi_{n}=26^{\circ}, L=2500\right.$ км $)$ 


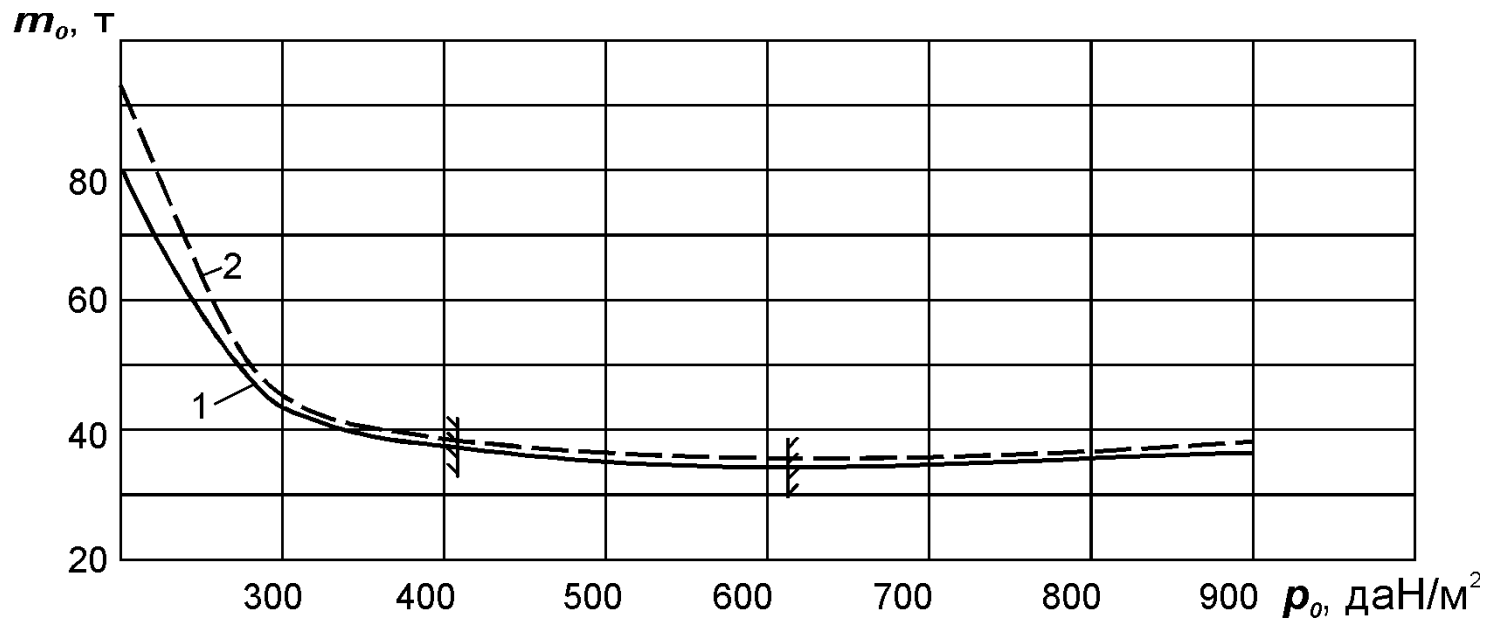

Рис. 9. Вплив питомого навантаження та стрілоподібності крила на злітну масу літака: $1-\chi_{n}=24^{\circ} ; 2-\chi_{n}=32^{\circ}(\lambda=9,6, \eta=4, L=2500$ км $)$

Для визначення діапазону параметрів можливих модифікацій розрахунок маси виконано для різних значень проектних параметрів.

На рисунках 10 - 12 зображено залежність злітної маси від довжини розбігу при різних значеннях параметрів загального вигляду, а на рисунках 13 15 - від дальності польоту 3 урахуванням компонування салону на 75 пасажирів.

У розрахунках злітної маси враховано обмеження питомого навантаження на крило за посадковою швидкістю і нормальним перевантаженням при польоті в турбулентній атмосфрері.

Аналогічним чином мінімальну масу визначено для модифікацій 3 компонуванням салону на 82 пасажири при дальності польоту 2100, 3500 і 4240 км. Отримані результати показано на рисунку 16.

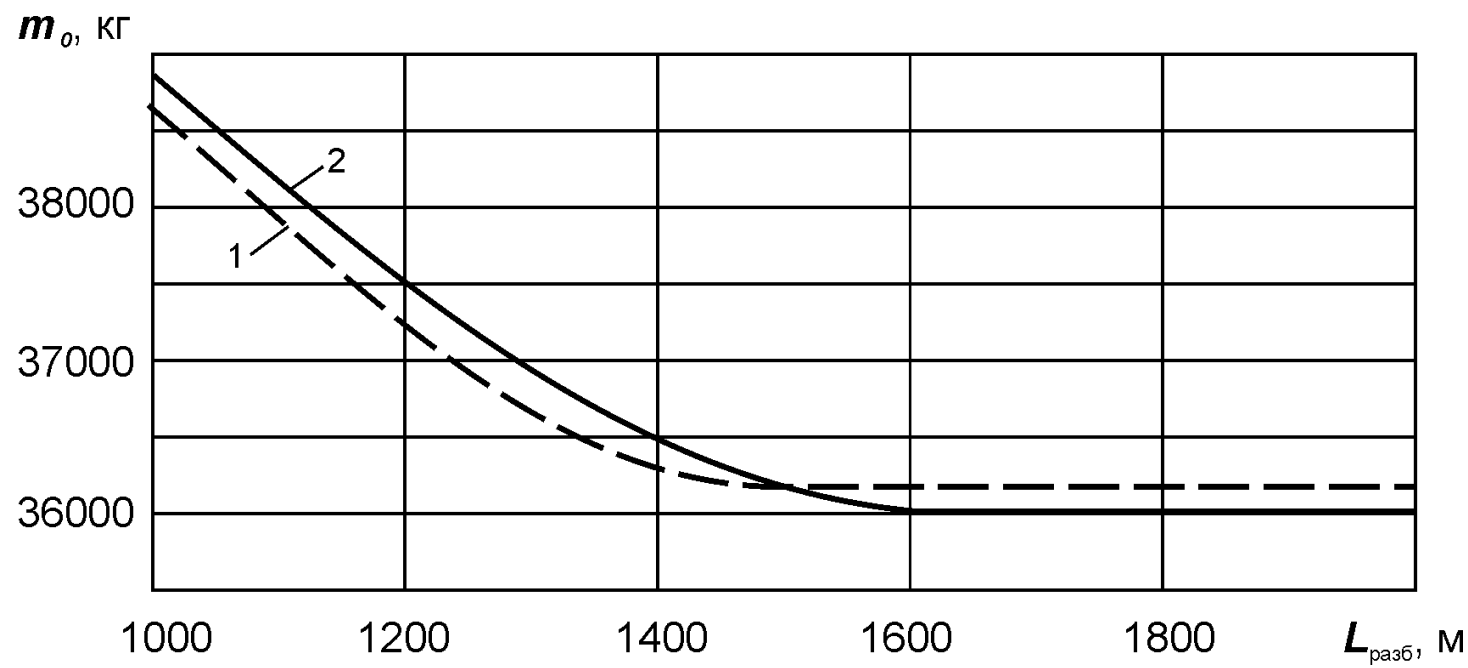

Рис. 10. Вплив питомого навантаження та подовження крила

на злітну масу літака: $1-\lambda=8 ; 2-\lambda=10\left(\eta=4, \chi_{n}=26^{\circ}, L=2500\right.$ км) 


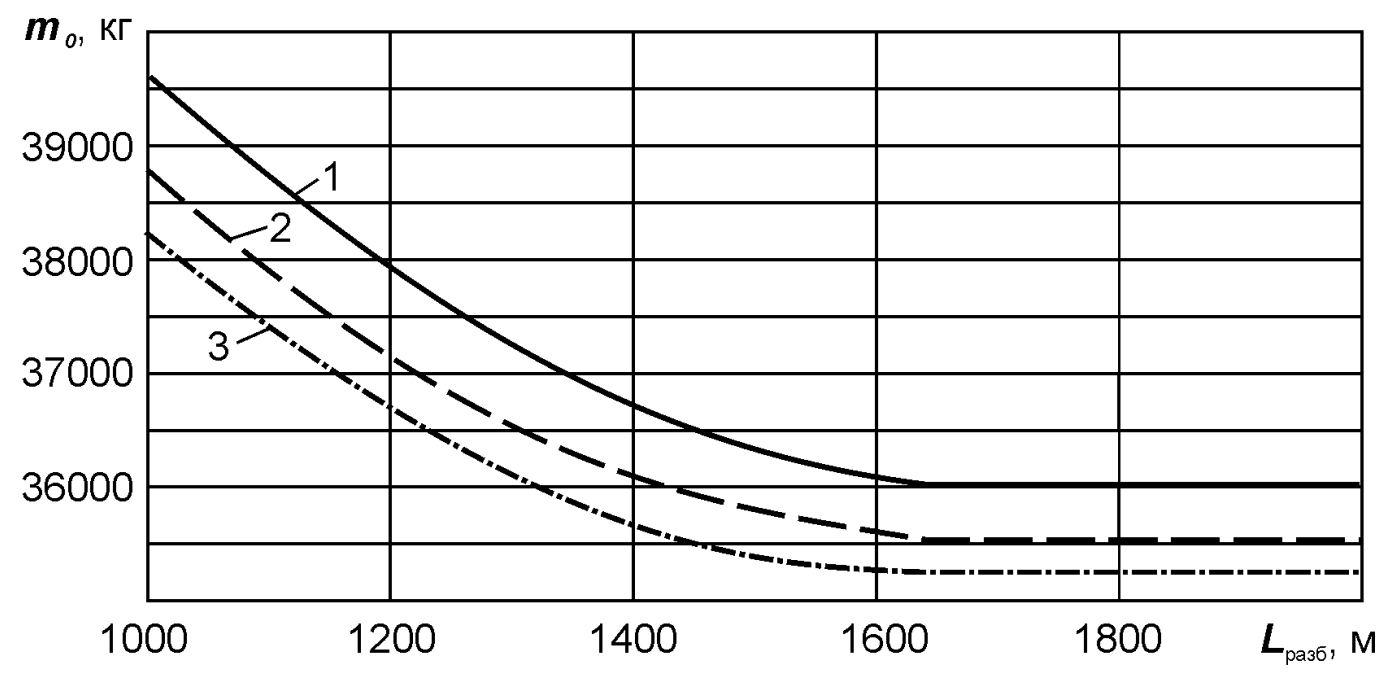

Рис. 11. Вплив довжини розбігу та звуження крила на злітну масу літака:

$$
1-\eta=3 ; 2-\eta=4 ; 3-\eta=5\left(\lambda=9,6, \chi_{n}=26^{\circ}, L=2500 \text { км }\right)
$$

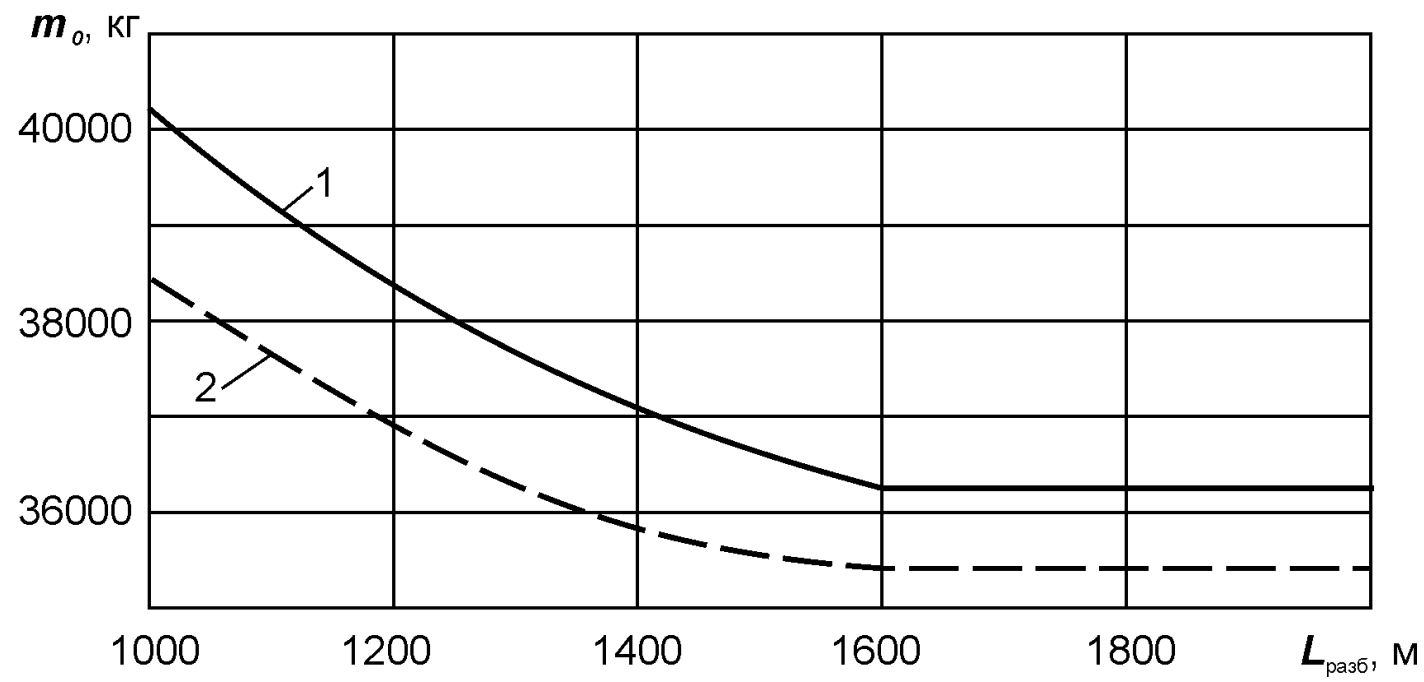

Рис. 12. Вплив довжини розбігу та стрілоподібності крила на злітну масу літака : $1-\chi_{n}=24^{\circ} ; 2-\chi_{n}=32^{\circ}(\lambda=9,6, \eta=4, L=2500$ км $)$

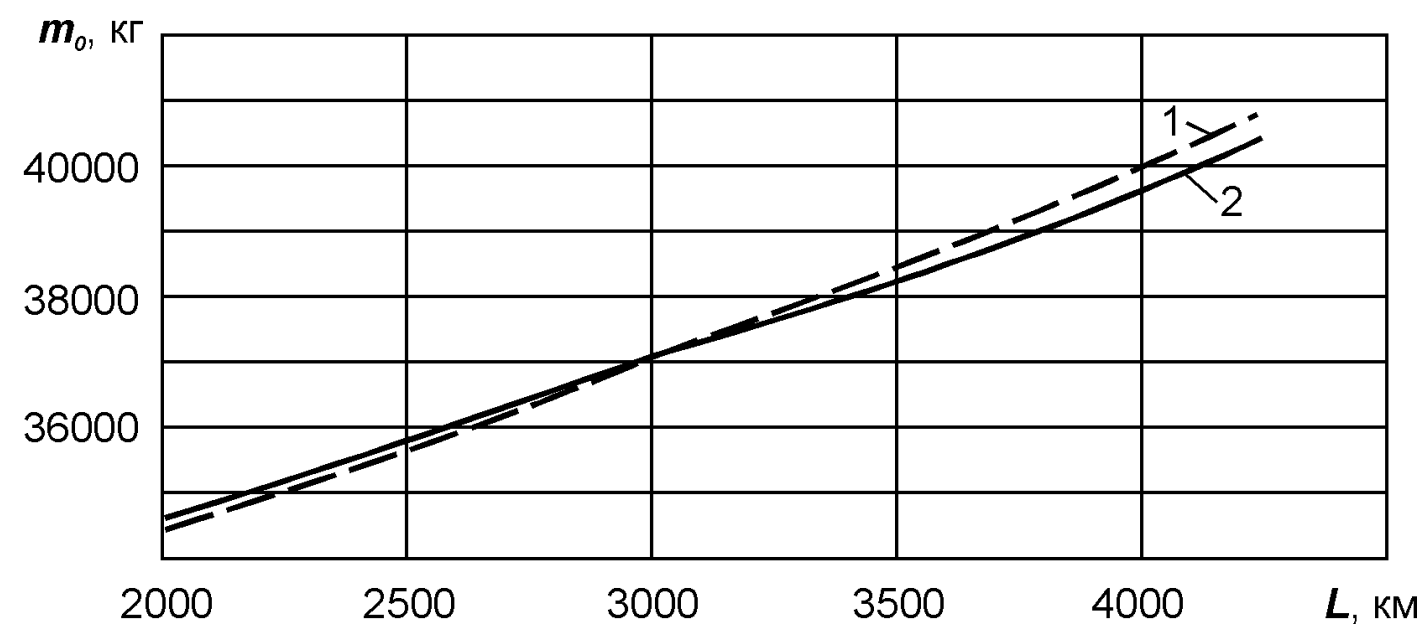

Рис. 13. Вплив дальності польоту та подовження крила

на злітну масу літака: $1-\lambda=8 ; 2-\lambda=10\left(\eta=4, \chi_{n}=26^{\circ}, L=2500\right.$ км $)$ 


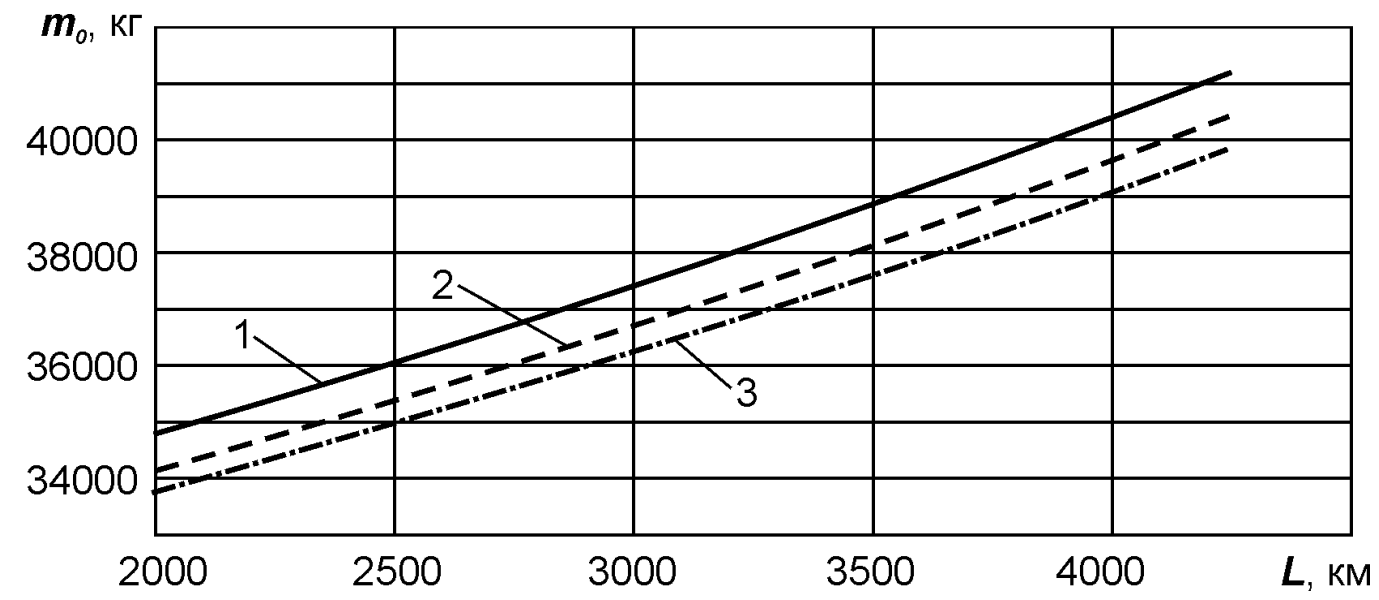

Рис. 14. Вплив дальності польоту та звуження крила на злітну масу літака:

$1-\eta=3 ; 2-\eta=4 ; 3-\eta=5\left(\lambda=9,6, \chi_{n}=26^{\circ}, L=2500\right.$ км $)$

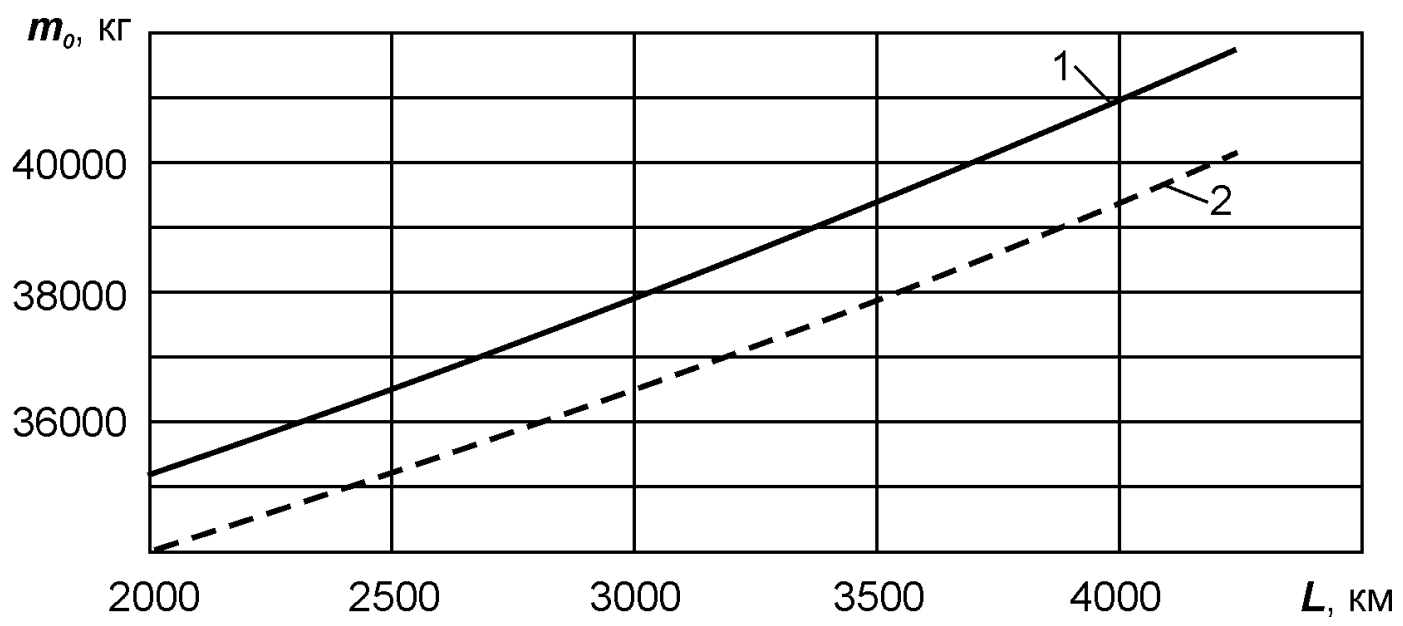

Рис. 15. Вплив дальності польоту та стрілоподібності крила на злітну масу літака: $1-\chi_{n}=32^{\circ} ; 2-\chi_{n}=24^{\circ}(\lambda=9,6, \eta=4, L=2500$ км $)$

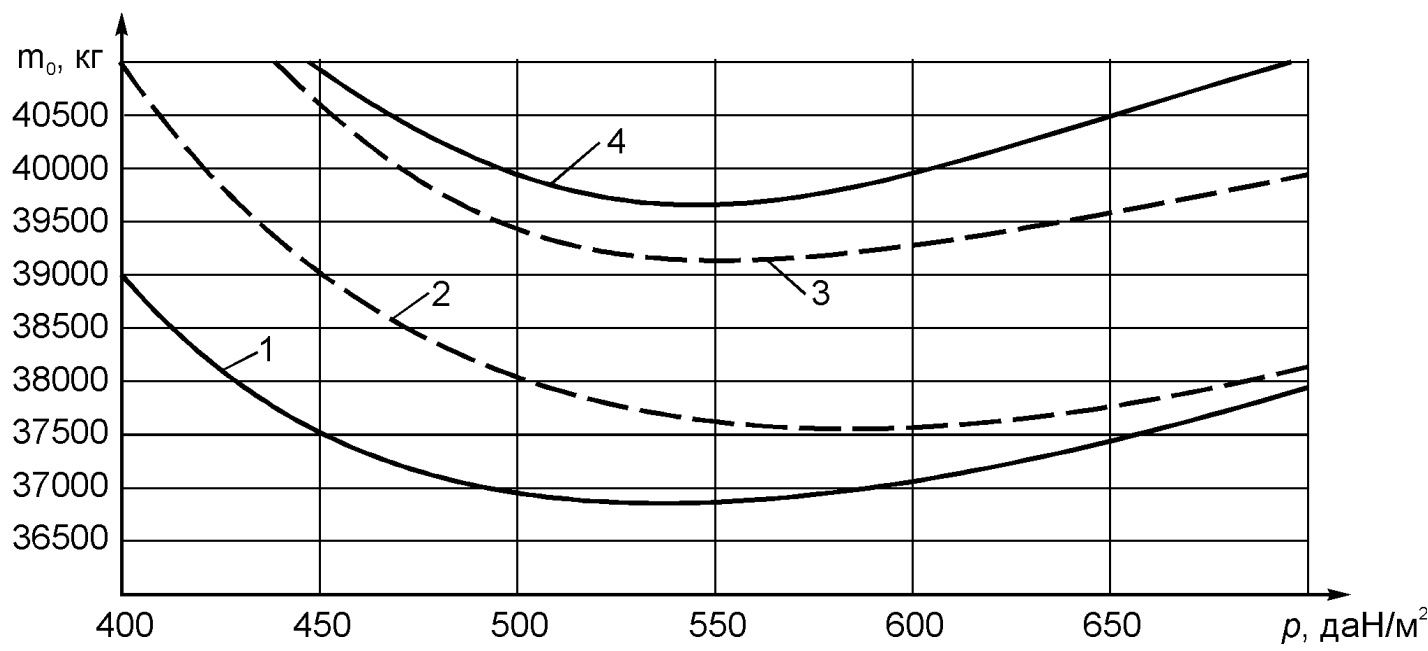

Рис. 16. Вплив питомого навантаження та подовження крила на злітну масу літака: $1-\lambda=8, L=2100$ км; $2-\lambda=10, L=2100$ км; $3-\lambda=10, L=4240 \mathrm{kм} ; 4-\lambda=8, L=4240$ км 
Порівняння пропонованих результатів розрахунків із характеристиками існуючих модифікацій літаків Ан-148 наведено у таблиці. Похибки розрахунків злітної маси не перевищує 3,5 \%, що свідчить о коректності отриманих результатів.

Порівняння результатів визначення злітної маси у першому наближенні із масами модифікацій літака Ан-148

\begin{tabular}{|c|c|c|c|}
\hline \multirow{2}{*}{ Параметри літака } & \multicolumn{3}{|c|}{ Модифікації літака } \\
\cline { 2 - 4 } & Ан-148-100A & Ан-148-100В & Ан-148-100Е \\
\cline { 2 - 4 } & $\begin{array}{c}L=2100 \mathrm{kM} \\
n_{n a c}=80\end{array}$ & $\begin{array}{c}L=3500 \text { км, } \\
n_{n a c}=80\end{array}$ & $\begin{array}{c}L=4200 \text { км, } \\
n_{n a c}=80\end{array}$ \\
\hline $\begin{array}{c}\text { Розрахована злітна } \\
\text { маса } m_{0}^{\prime}, \text { кг }\end{array}$ & 38090 & 41530 & 42150 \\
\hline $\begin{array}{c}\text { Злітна маса існуючої } \\
\text { модифрікації, кг }\end{array}$ & 38950 & 41950 & 43700 \\
\hline Похибка, \% & 2,2 & 1 & 3,5 \\
\hline
\end{tabular}

Заданий рівень масової досконалості конструкції передбачається забезпечити шляхом широкого застосування композиційних матеріалів (КМ). Вертикальне й горизонтальне оперення має бути повністю виконано з КМ, як і носок, закінцівки й уся механізація крила (передкрилок, закрилки, елерони, тримери і сервокомпенсатори). Фюзеляж, кесон крила і центроплана слід виготовляти з алюмінієвих сплавів, щоб зберегти технологічну спадкоємність і спростити підготовку до виробництва машини на вітчизняних авіапідприємствах. Завдяки значному застосуванню КМ і розширеному використанню методів інтегрованого проектування з урахуванням втоми розрахункова відносна маса конструкції виходить на $15 . .20 \%$ меншою, ніж існуючих аналогів при заданому проектному ресурсі планера 80000 год. Це має забезпечити проектний термін експлуатації літака 30 років при річному нальоті 2800 - 3500 год.

За результатами аналізу ТTX двигуна і аеродинамічних характеристик літака зроблено висновок, що для забезпечення заданого рівня паливної ефективності $(0,0245$ кг/пас.-км) на крейсерському режимі польоту необхідно забезпечити крейсерську аеродинамічну якість літака не нижче 16-17. Із врахуванням вимог ТЗ щодо експлуатації літака на грунтових і необладнаних аеродромах вирішено питання про розташування крила за схемою «високоплан» і розміщення двигунів над крилом. За попередніми розрахунками для забезпечення заданої дистанції зльоту необхідним $€$ досягнення злітнопосадкової якості $10-12$ при $\boldsymbol{C}_{\boldsymbol{y}}=2,4$. Виконані розрахунки свідчать, що крило потребує оптимізації геометричних параметрів з використанням САПР. Тому вирішено питання про застосування стрілоподібного крила великого подовження з автоматичним багатосекційним передкрилком і багатощілинним двосекційним закрилком з навантаженням на крило від 500 до 550 даН//2 Оптимізацію слід проводити за аеродинамічною якістю на крейсерському режимі за умови забезпечення заданих злітно-посадкових характеристик з урахуванням застосування механізації. Доцільно забезпечити величину аеродинамічної якості 
для крейсерського режиму 18. Подальші роботи щодо поліпшення аеродинамічної досконалості літака будуть проводитися при більш ретельному опрацюванні аеродинамічного компонування шляхом підбору оптимальної аеродинамічної і геометричної скрученості крила, а також у процесі уточнення взаємного впливу різних агрегатів конструкції літака.

Зроблені розрахунки дозволяють на етапі розроблення аванпроекту виконати креслення загального вигляду й перейти до наступних етапів інтегрованого проектування. Наприклад проведено розрахунки геометричних параметрів загального вигляду літака та отримано такі результати [4]:

- площа крила - 87,3 м²; - розмах крила - 28,9 м;

- коренева хорда крила - 4,83 м; - кінцева хорда крила - 1,2 м;

- середня аеродинамічна хорда крила - 3,4 м;

- площа горизонтального оперення - 17,95 м²;

- розмах горизонтального оперення - 9,346 м;

- площа вертикального оперення - 19,91 м²;

- довжина фюзеляжу - 26,2 м; - діаметр фюзеляжу - 3,5 м.

- плече горизонтального оперення - 20,3 м.

Для літака з високим розташуванням крила висота шасі визначається мінімальною відстанню від нижньої точки фююзеляжу до поверхні злітнопосадкової смуги.

Згідно з отриманими геометричними параметрами розроблено креслення загального вигляду літака (рисунок 17).

Параметричне моделювання літака виконано за допомогою системи Siemens NX. Розроблено математичні моделі та створено майстер-геометрії агрегатів літака та проведено їх взаємну ув'язку. Внаслідок цього отримано параметричну майстер-геометрію проектованого літака (рисунок 18), 3 якою асоціативно пов'язані всі конструктивні елементи.

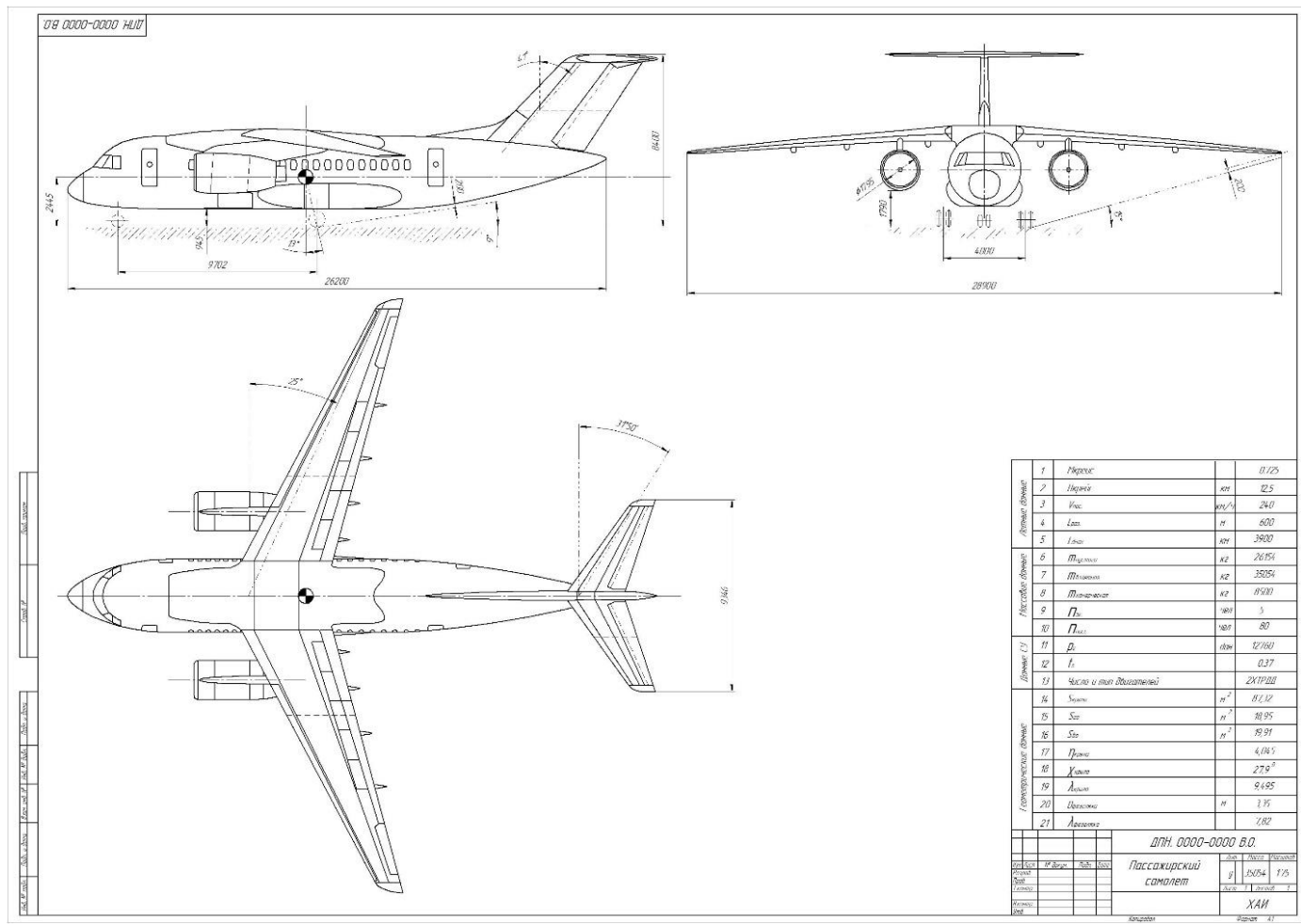

Рис. 17. Загальний вигляд літака 


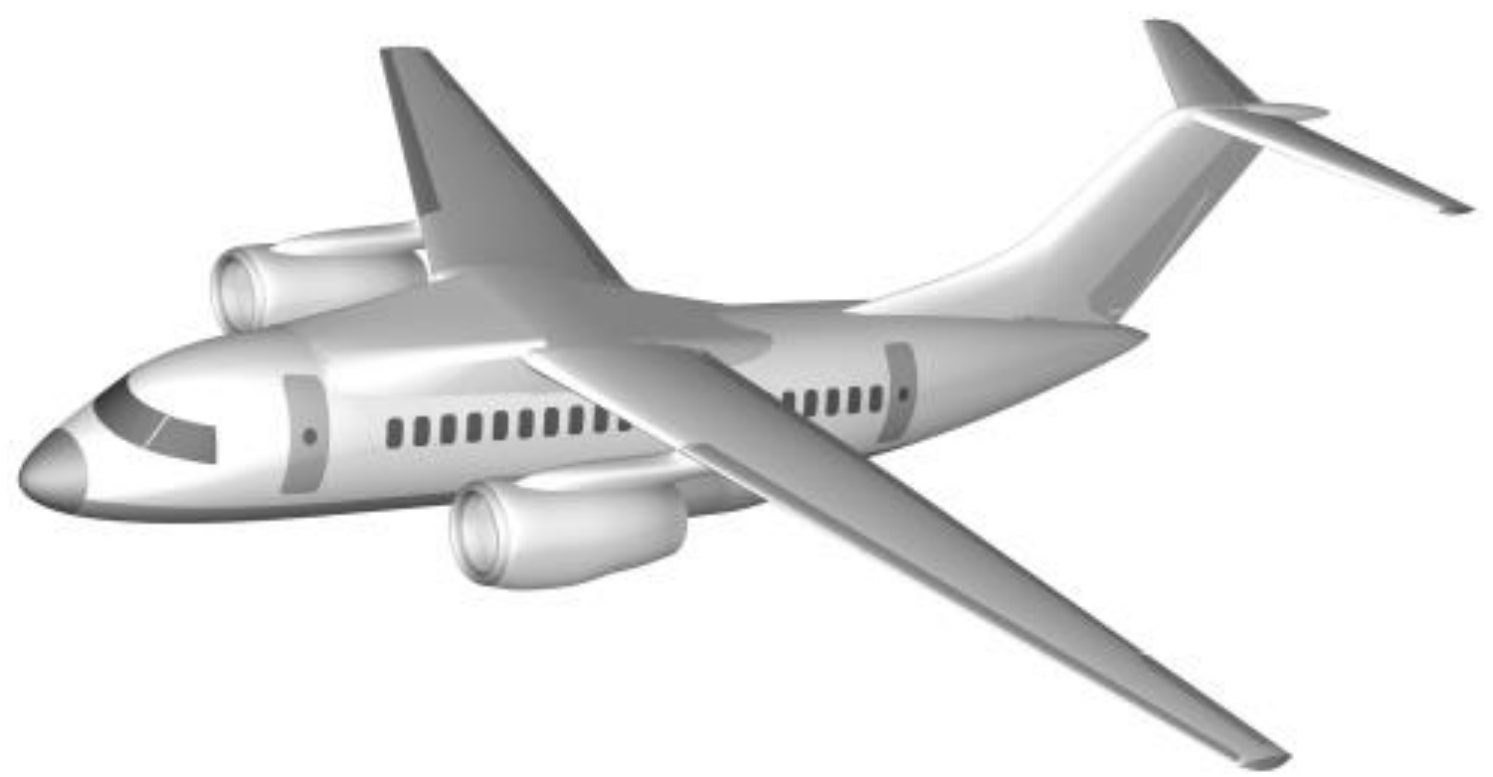

Рис. 18. Параметрична модель майстер-геометрії регіонального пасажирського літака

Розроблено модель розподілу простору літака та його агрегатів. На рисунку 19 зображено фррагмент моделі розподілу простору крила літака.

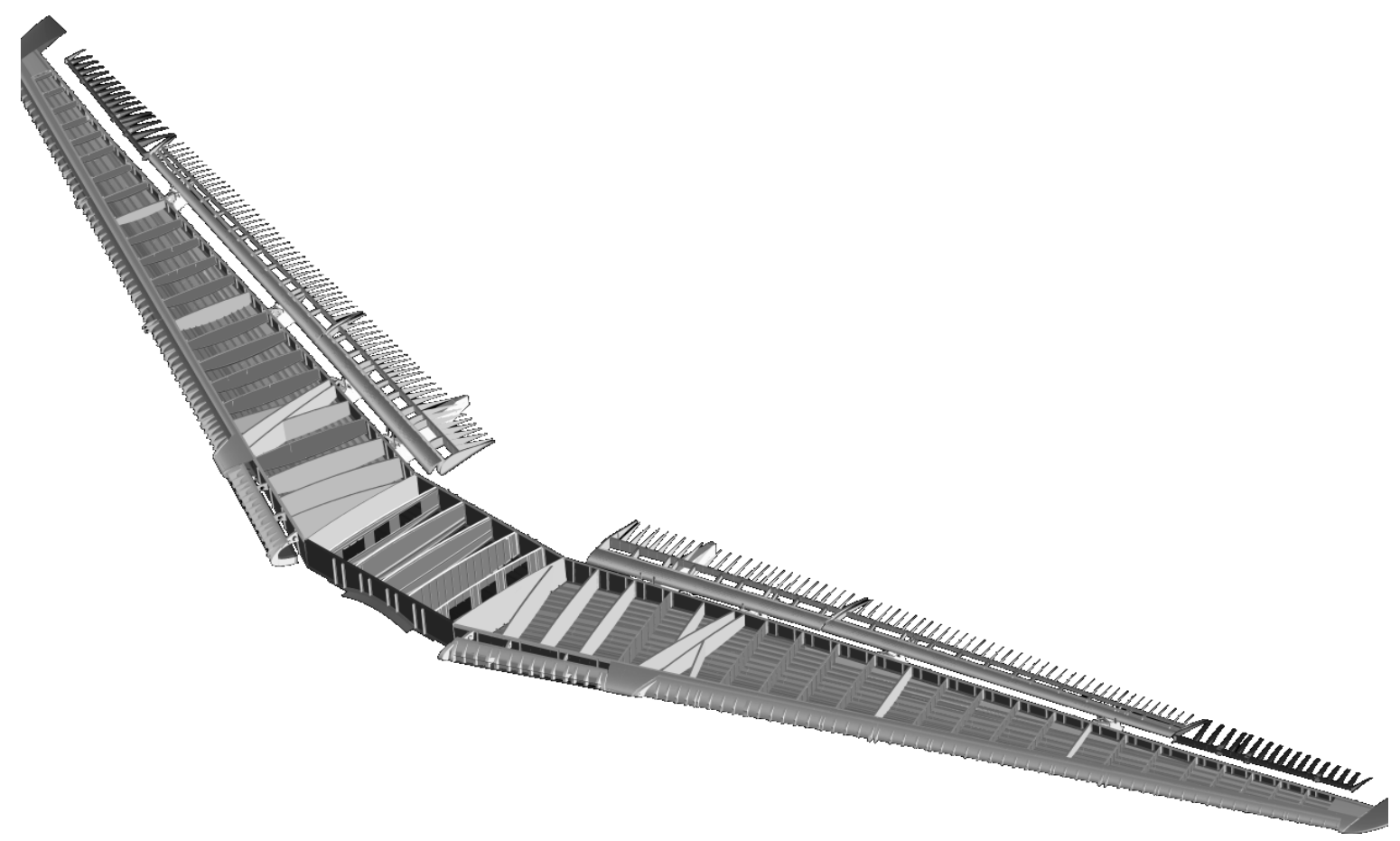

Рис. 19. Фрагмент моделі розподілу простору крила літака

Таким чином, продемонстровано реалізацію принципу створення майстер-геометрії обліку літака.

Реалізація пропонованого принципу проектування агрегатів літака дозволяє окрім тривимірної комп'ютерної моделі майстер-геометрії літака, що проектується, розробити моделі розподілу простору. Для створення моделі розподілу простору літака необхідно вирішити такі задачі: розробити конструктивно-технологічне членування; панелювання; визначити кількість та 
розташування елементів конструктивно-силового набору; вирішити питання переліку та розміщення обладнання, устаткування та інші; компонування систем; компонування кабіни екіпажу та пасажирського салону для різної кількості пасажирів та комфортабельності салону. Крім того виконуються компонування та розрахунки діапазону положення центра мас літака у цілому. Розроблення варіантів компонування пасажирського салону та розрахунки центрівок описано у роботі [4]. Наступний крок - створення аналітичних еталонів силових елементів конструкцій на базі низки проектувальних та перевірочних розрахунків регулярних зон та зон конструктивних нерегулярностей. Вони створюються методами аналітичної геометрії за допомогою інтегрованих систем CAD $\backslash C A M \backslash C A E \backslash P L M$ в єдиному інформаційному середовищі підтримки життєвого циклу літака. На рисунках 20 та 21 показано аналітичний еталон верхньої люкової панелі центроплана та нервюри консольної частини крила.

Після визначення параметрів з'єднань в регулярних та нерегулярних зонах конструкції на основі параметричних моделей розподілу простору та аналітичних еталонів деталей і складених вузлів літака створено параметричні моделі повного визначення агрегатів та літака в цілому. На рисунку 22 показано модель повного визначення хвостового оперення, а на рисунку 23 - фрагмент моделі повного визначення регіонального пасажирського літака.

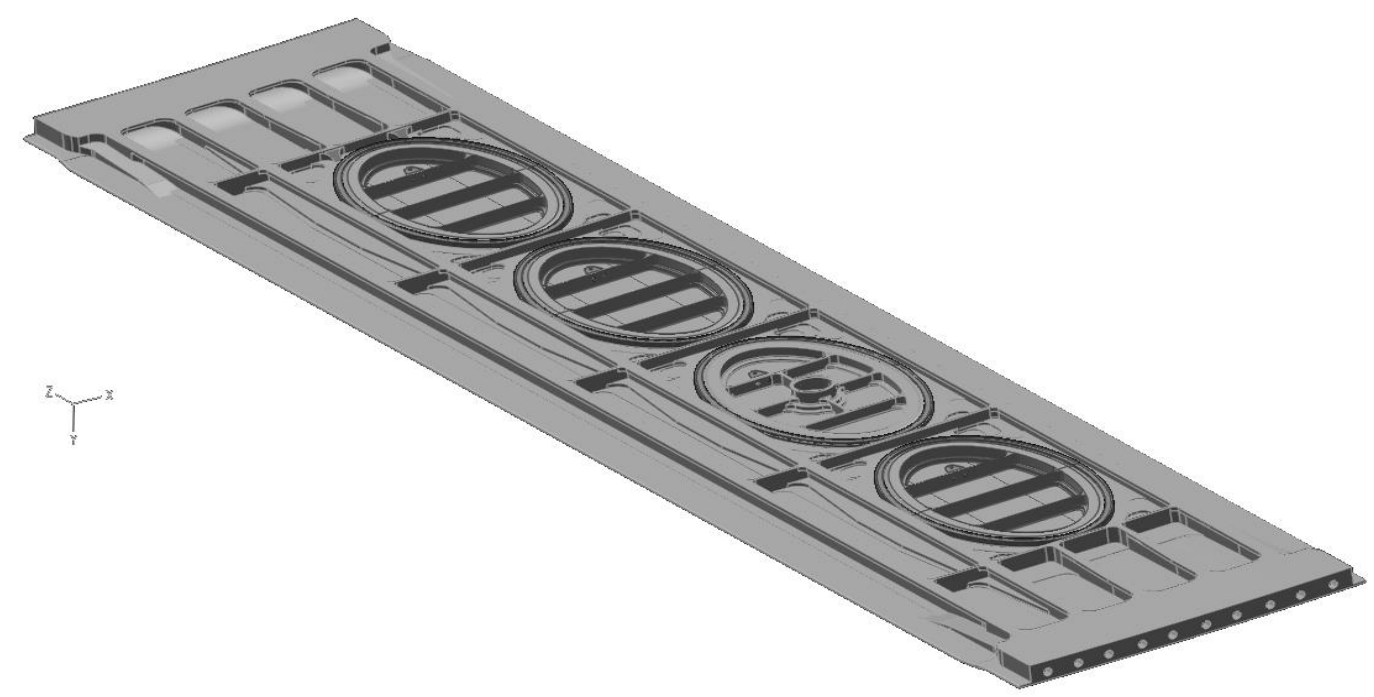

Рис. 20. Аналітичний еталон верхньої люкової панелі центроплана

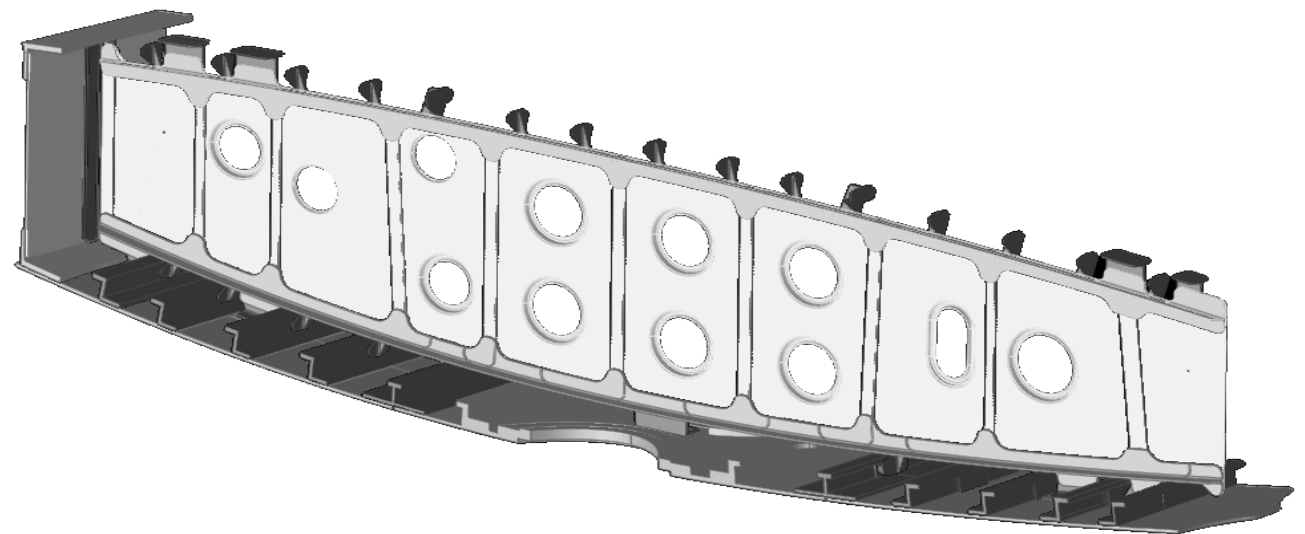

Рис. 21. Аналітичний еталон типової нервюри консольної частини крила 


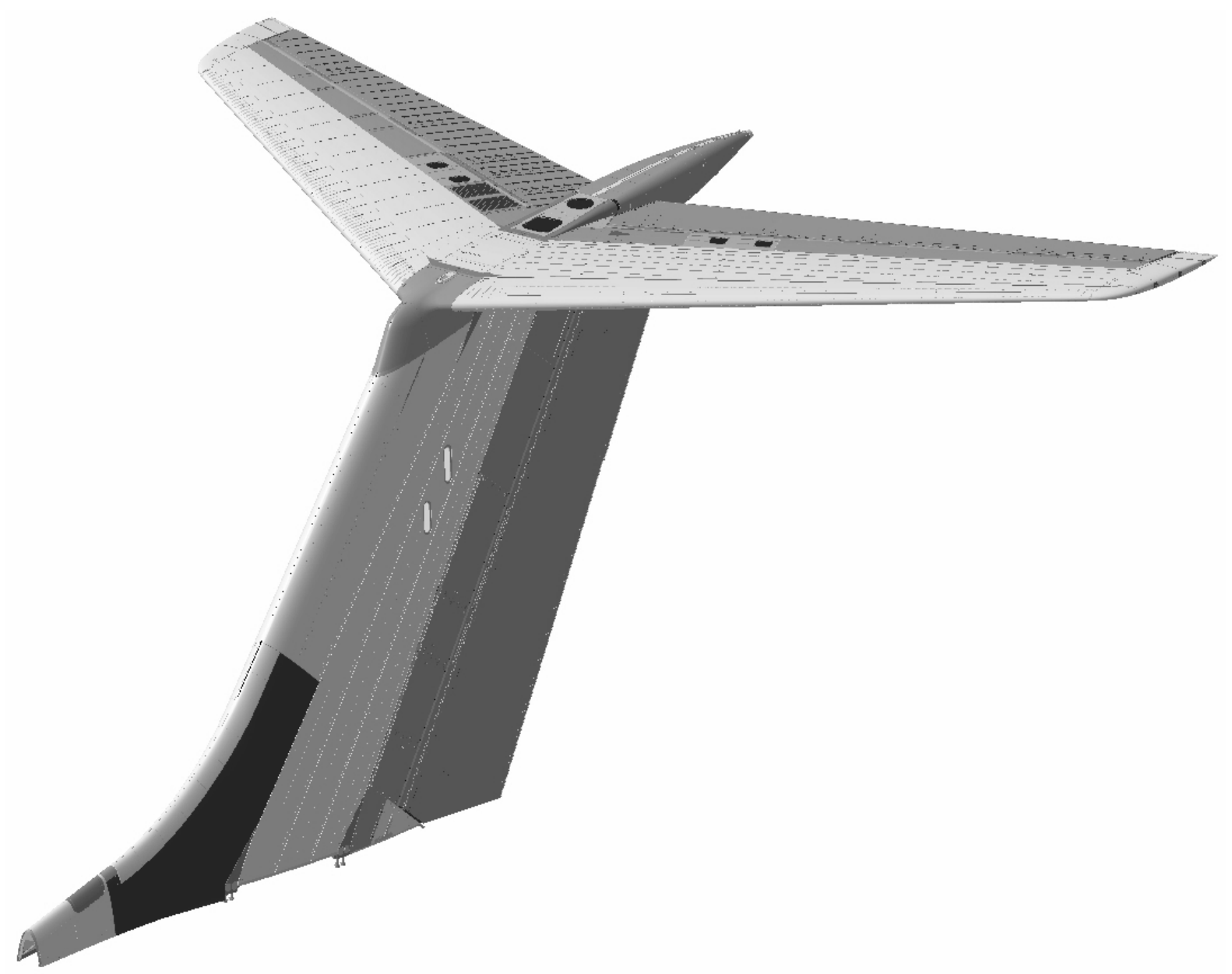

Рис. 22. Модель повного аналітичного визначення хвостового оперення літака

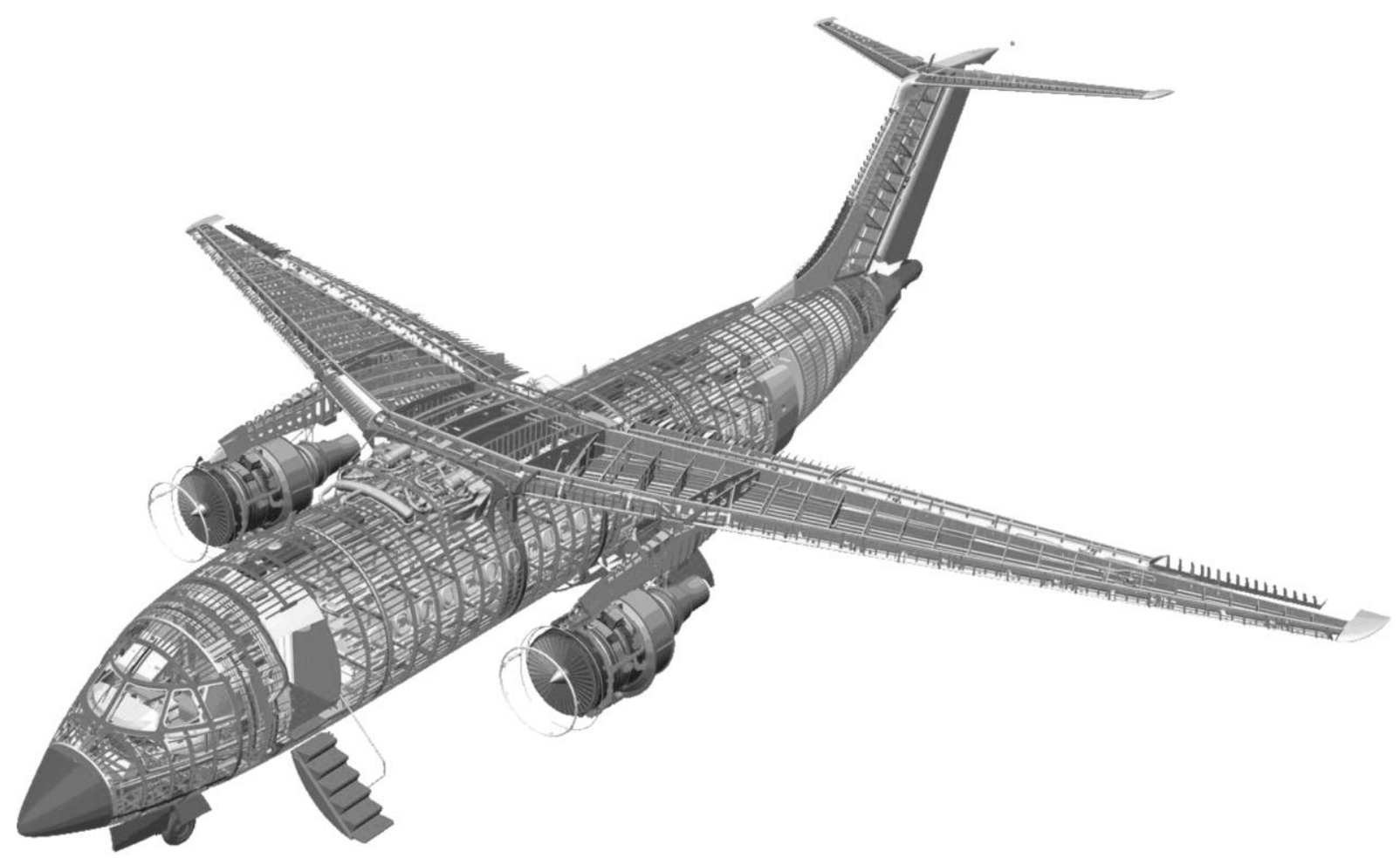

Рис. 23. Фрагмент моделі повного визначення літака 
Таким чином, застосування запропонованих концепції та принципів проектування та використання CAD/CAM/CAE систем в єдиному інформаційному просторі дозволяє суттєво збільшити ефективність проектування літака в цілому та його агрегатів.

\section{Висновки}

Запропоновано концепцію та принципи інтегрованого проектування конкурентоспроможних регіональних пасажирських літаків, призначених для перевезення пасажирів, багажу, пошти та вантажів на внутрішніх і міжнародних авіалініях з можливістю експлуатації на аеродромах зі штучним покриттям і підготовлених ґрунтових злітно-посадкових смугах. Планується, що літак зможе замінити літаки попереднього покоління в парку регіональних пасажирських літаків авіакомпаній різних країн. Актуальність робіт 3 цієї тематики підтверджена потребами сучасного ринку авіаційних перевезень та необхідністю створення конкурентоспроможної техніки.

Інтегроване проектування літаків базується на використанні аналітичних методів розрахунків 3 можливостями інтегрованих комп'ютерних систем $\mathrm{CAD} / \mathrm{CAM} / \mathrm{CAE}$. Показано їх взаємних зв'язок та взаємозалежність. Наведено приклади створення майстер-геометрії літака, моделі розподілу його простору, аналітичних еталонів.

Особливості концепції та принципів проектування регіональних пасажирських літаків апробовано 3 використанням параметрів літаків ДП «Антонов» ряду Ан-148.

При виконанні наведених розрахунків продемонстровано вплив параметрів зовнішнього вигляду на технічні характеристики літака, що проектується.

Порівняння результатів застосування особливостей проектування, що пропонуються, із параметрами існуючих літаків ряду Ан-148 свідчить про коректність розробленого.

\section{Список літератури}

1. Гражданское самолетостроение в начале XXI столетия. Деятельность ведущих мировых производителей / Г. А. Кривов, В. А. Матвиенко, А. А. Щербак, Т. Н. Щедрина. Киев: КИТ, 2008. - 168 с.

2. Пядушкин, М. Перевозчики удивили авиастроителей // Авиатранспортное обозрение. - 2007. - № 78. - С 13 - 15.

3. Гребеников, А.Г. Методология интегрированного проектирования и моделирования сборных самолетных конструкций / А. Г. Гребеников. - Харьков: ХАИ, 2006. - 532 с.

4. Метод загального проектування регіональних пасажирських літаків / О.Г.Гребеніков, О.Д.Донець, С. В.Трубаєв, А. С. Чумак // Открытые информационные и компьютерные интегрированные технологии: сб. науч. тр. Нац. аэрокосм. ун-та им. Н.Е. Жуковского «Харьк. авиац. ин-т». - Вып. 85. - Харьков, 2019. - C. 4 - 31. DOI: 10.32620/oikit.2019.85.01.

5. Ian Goold. Bombardier Sees Need For 11,000 20- To 149-Seaters Over 20 Years // Aviation International News, Farnborough International Air Show Daily. 2006. - 19.07. - P.5. 
6. Нормы летной годности самолетов транспортной категории (АП-25). - М.: MAK, 2009 - 322 c.

7. Certification Specifications and Acceptable Means of Compliance for Large Aeroplanes. - EASA, $2019-1135$ c.

8. Кива, Д. С. Научные основы интегрированного проектирования самолетов транспортной категории: монография. В 3 ч. / Д. С. Кива, А. Г. Гребеников. Харьков: ХАИ, 2014. - Ч. 2. - 326 с.

9. Проектирование самолетов: учеб. для вузов / С. М. Егер, В. Ф. Мишин, Н. К. Лисейцев и др.; под ред. С. М. Егера. - 3-е изд., перераб. и доп. - М.: Машиностроение, 1983. - 616 с.

10. Шейнин, В. М. Весовое проектирование и эфффективность пассажирских самолетов: справочник / В. М. Шейнин, В. И. Козловский. - 2-е изд., перераб. и доп. - М.: Машиностроение, 1984. - 552 с.

11. Информационные технологии в наукоемком машиностроении: компьютерное обеспечение индустриального бизнеса/ под. общ. ред. А. Г. Братухина. - Киев: Техніка, 2001. - 728 с.

12. Холявко, В. И. Расчет аэродинамических характеристик самолета: учеб. пособие в 2 ч. Ч. 1 / В. И. Холявко. -Харьков: ХАИ, 1991. - 72 с.

13. Торенбик, Э. Проектирование дозвуковых самолетов: / Э. Торенбик, Е.П. Голубков, пер. с англ. - М.: Машиностроение, 1983. - 648 с.

14. Основи загального проектування літаків з газотурбінними двигунами: навч. посіб. / П. В. Балабуєв, С. А. Бичков, О. Г. Гребеніков та ін. - Харків: ХАІ, 2015. $-815 \mathrm{C}$.

15. Самолет Ан-140. Стандартная спецификация: учебник / П. В. Балабуев, А.Г. Гребеников, П. А. Клюев и др. - Харьков: ХАИ, 2004. - 260 с.

16. Самолет Ан-74 ТК-300. Стандартная спецификация: учебник / А. Г. Гребеников, П. А. Клюев, В. Н. Король и др. - Харьков: ХАИ, 2004. - 277 с.

17. Стандартная спецификация на тип самолета (вертолета): учебник / А. Г. Гребеников, П. А. Клюев, В. Н. Король и др. - Харьков: ХАИ, 2004. - 336 с.

\section{References}

1. Grazhdanskoe samoletostroenie v nachale XXI stoletija. Dejatel'nost' vedushhih mirovih proizvoditelej / G. A. Krivov, V. A.Matvienko, A. A. Shherbak, T. N. Shhedrina. Kiev: KIT, 2008. - 168 s.

2. Pjadushkin, M. Perevozchiki udivili aviastroitelej // Aviatransportnoe obozrenie. 2007. - № 78. - S 13 - 15.

3. Grebenikov, A. G. Metodologija integrirovannogo proektirovanija i modelirovanija sbornyh samoletnyh konstrukcij / A. G. Grebenikov. - Har'kov: HAI, 2006. - 532 s.

4. Metod zagal'nogo proektuvannja regional'nih pasazhirs'kih litakiv / O. G. Grebenikov, O. D. Donec', S. V. Trubaev, A. S. Chumak // Otkrytye informacionnye i komp'juternye integrirovannye tehnologii: sb. nauch. tr. Nac. ajerokosm. un-ta im. N.E. Zhukovskogo «Har'k. aviac. in-t». - Vyp. 85. - Har'kov, 2019. - S. 4 - 31. DOI: 10.32620/oikit.2019.85.01.

5. Ian Goold. Bombardier Sees Need For 11,000 20- To 149-Seaters Over 20 Years // Aviation International News, Farnborough International Air Show Daily. - 2006. - 19.07. - P.5. 
6. Normy letnoj godnosti samoletov transportnoj kategorii (AP-25). - M.: MAK, 2009 $-322 \mathrm{~s}$.

7. Certification Specifications and Acceptable Means of Compliance for Large Aeroplanes. - EASA, 2019 - 1135 s.

8. Kiva, D. S. Nauchnye osnovy integrirovannogo proektirovanija samoletov transportnoj kategorii: monografija. V 3 ch. / D. S. Kiva, A. G. Grebenikov. Har'kov: HAl, 2014. - Ch. 2. - 326 s.

9. Proektirovanie samoletov: ucheb. dlja vuzov / S. M. Eger, V. F. Mishin, N. K. Lisejcev i dr.; pod red. S. M. Egera. - 3-e izd., pererab. i dop. - M.: Mashinostroenie, 1983. - $616 \mathrm{~s}$.

10. Shejnin, V. M. Vesovoe proektirovanie i jeffektivnost' passazhirskih samoletov [Tekst] : spravochnik / V. M. Shejnin , V. I. Kozlovskij. - 2-e izd., pererab. i dop. M.: Mashinostroenie, 1984. - $552 \mathrm{~s}$.

11. Informacionnye tehnologii $v$ naukoemkom mashinostroenii: komp'juternoe obespechenie industrial'nogo biznesa/ pod. obshh. red. A. G. Bratuhina. - Kiev: Tehnika, 2001. - $728 \mathrm{~s}$.

12. Holjavko, V. I. Raschet ajerodinamicheskih harakteristik samoleta. [Tekst] : ucheb. posobie v 2 ch. Ch. 1 / V. I. Holjavko. - Har'kov: HAI, 1991. - 72 s.

13. Torenbik, Je. Proektirovanie dozvukovyh samoletov: / Je. Torenbik, E.P. Golubkov, per. s angl. - M.: Mashinostroenie, 1983. - 648 s.

14. Osnovi zagal'nogo proektuvannja litakiv z gazoturbinnimi dvigunami: navch. posib. / P. V. Balabuev, S. A. Bichkov, O. G. Grebenikov ta in. - Harkiv: HAI, 2015. -815 s.

15. Samolet An-140. Standartnaja specifikacija: uchebnik / P. V. Balabuev, A. G. Grebenikov, P. A. Kljuev i dr. - Har'kov: HAI, 2004. - 260 s.

16. Samolet An-74 TK-300. Standartnaja specifikacija: uchebnik / A. G. Grebenikov, P. A. Kljuev, V. N. Korol' i dr. - Har'kov: HAl, 2004. - 277 s.

17. Standartnaja specifikacija na tip samoleta (vertoleta): uchebnik / A. G. Grebenikov, P. A. Kljuev, V. N. Korol' i dr. - Har'kov: HAI, 2004. - 336 s.

Надійшло до редакції 05.12.2019, розглянута на редколегії 18.12.2019.

\section{Особенности интегрированного проектирования региональных пассажирских самолетов}

\footnotetext{
Приведены особенности интегрированного проектирования конкурентоспособных региональных пассажирских самолетов, предназначенных для перевозки пассажиров, багажа, почты и грузов на внутренних и международных авиалиниях с возможностью эксплуатации на аэродромах с искусственным покрытием и подготовленных грунтовых взлетнопосадочных полос (ВПП). Применение предложенных особенностей концепции и принципов позволит создать самолёты для замены предыдущего поколения парка региональных пассажирских самолётов. Концепция и принципы базируются на использовании систем интегрированного проектирования и производства.
} 
Предложен метод исследования влияния параметров самолета на аэродинамические и массовые характеристики при условии выполнения требований авиационных правил (АП). Метод апробирован при интегрированном проектировании различных модификаций пассажирских самолетов ГП «Антонов».

Описаны особенности создания трехмерной компьютерной модели мастер-геометрии проектируемого самолета, разработки модели распределения пространства, аналитических эталонов силовых элементов конструкции, которые создаются методами аналитической геометрии при помощи компьютерных интегрированных систем CAD/CAM/CAE/PLM в едином информационном пространстве поддержки жизненного цикла самолета.

Основные технические характеристики самолета, проектируемого с учетом предложенных особенностей, полностью соответствуют нормам летной годности и превышают характеристики самолетов-аналогов. При необходимости можно учесть особенности эксплуатации самолета на аэродромах с малоподготовленными и грунтовыми ВПП, обеспечить возможность его использования на любых воздушных линиях, в простых и сложных метеоусловиях, днем и ночью, а также на маршрутах с высокой интенсивностью полётов при высоком уровне комфорта, что обеспечивает высокий уровень конкурентоспособности самолета на мировом рынке.

Ключевые слова: самолет; проектирование; общий вид; параметры; расчет массы; компоновка; параметрическая модель; мастер-геометрия самолета; модель распределения пространства; аналитические эталоны силовых элементов конструкции; аэродинамическое качество; конкурентоспособность.

\section{Features of Integrated Design of Regional Passenger Aircraft}

The features of the integrated design of competitive regional passenger airplanes intended to carry passengers, baggage, mail and cargo on domestic and international airlines with the possibility of operation at paved aerodromes and prepared unpaved runways are given. It is planned that application of the proposed features of the concept and principles, and their implementation will create aircraft to replace the previous generation of the regional passenger aircraft fleet of airlines of different countries. The concept and principles of its implementation are based on the use of integrated design and production systems. The proposed opportunity to study influence of aircraft parameters on aerodynamic and mass characteristics, provided that the requirements of Aviation Regulations (AP) for the layout and flight safety are met. For testing, the results of such studies shown for various modifications of passenger aircraft of the ANTONOV State Company.

The features of creating a three-dimensional computer model of the designed aircraft master geometry, developing a space distribution model, analytical standards for structural load-bearing elements designed using analytical geometry methods with the help of integrated CAD $\backslash$ CAM $\backslash$ CAE $\backslash$ PLM systems in a single information environment for supporting the aircraft life cycle are shown.

The aircraft under design must fully comply with the AP-25 Airworthiness Requirements.

The main technical characteristics of the designed aircraft, taking into account the proposed solutions, are close in magnitude to the characteristics of the similar 
aircraft. If necessary it is possible to take into account the peculiarities of aircraft operation at aerodromes with badly paved and unpaved runways to provide the opportunity of its usage on any airways, in simple and difficult weather conditions, during day and night, as well as on routes with a high flight intensity with a high level of crew comfort, which will ensure a high level of competitiveness of the aircraft in the world market.

Key words: airplane; design; overall view; parameters; mass calculation; layouts; parametric model; aircraft master geometry; space distribution model; analytical standards of structural load-bearing elements; lift-to-drag ratio; competitiveness.

\section{Відомості про авторів:}

Гребеніков О. Г., зав. каф. № 103 Національного аерокосмічного університету iм. M. Є. Жуковського «XAI». ORCID: 0000-0002-1509-0665

Гуменний А. М., доц. каф. № 103 Національного аерокосмічного університету ім. М. Є. Жуковського «XAI». ORCID: 0000-0003-1020-6304

Донець О. Д., президент ДП «Антонов».

Трубаєв С. В., доц. каф. 103 № Національного аерокосмічного університету ім. М. Є. Жуковського «XAl».

Чумак А. С., ст. викл. каф. 103 № Національного аерокосмічного університету ім. М. Є. Жуковського «XAI». ORCID 0000-0003-2913-7038

\section{About the Authors}

Grebenikov O. G., Head of Department 103, National Aerospace University named by M. E. Zhukovsky "KhAl". ORCID: 0000-0002-1509-0665

Humenny A. M., Assistant professor of Department 103, National Aerospace University named by M. E. Zhukovsky "KhAl". ORCID: 0000-0003-1020-6304

Donets O. D., President of the ANTONOV State Enterprise.

Trubaev S.V., Assistant professor of Department 103, National Aerospace University named by M. E. Zhukovsky "KhAl".

Chumak A. S., Senior lecturer of Department 103, National Aerospace University named by M. E. Zhukovsky "KhAl". ORCID 0000-0003-2913-7038 